This item was submitted to Loughborough's Research Repository by the author.

Items in Figshare are protected by copyright, with all rights reserved, unless otherwise indicated.

\title{
International knowledge brokerage and returnees' entrepreneurial decisions
}

PLEASE CITE THE PUBLISHED VERSION

http://dx.doi.org/10.1057/jibs.2016.1

\section{PUBLISHER}

(C) Palgrave Macmillan

\section{VERSION}

AM (Accepted Manuscript)

\section{PUBLISHER STATEMENT}

This work is made available according to the conditions of the Creative Commons Attribution-NonCommercialNoDerivatives 4.0 International (CC BY-NC-ND 4.0) licence. Full details of this licence are available at: https://creativecommons.org/licenses/by-nc-nd/4.0/

\section{LICENCE}

CC BY-NC-ND 4.0

\section{REPOSITORY RECORD}

Lin, Daomi, Jiangyong Lu, Xiaohui Liu, and Xiru Zhang. 2016. "International Knowledge Brokerage and Returnees' Entrepreneurial Decisions”. Loughborough University. https://hdl.handle.net/2134/20052. 


\title{
International knowledge brokerage and returnees' entrepreneurial decisions
}

\author{
Daomi Lin \\ Guanghua School of Management, Peking University \\ No. 5 Yiheyuan Road, Beijing, 100871 \\ Tel: 86-15010178381 \\ Email: lindaomi@pku.edu.cn \\ Jiangyong $\mathbf{L u}{ }^{1}$ \\ Guanghua School of Management, Peking University \\ No. 5 Yiheyuan Road, Beijing, 100871 \\ Tel: 86-10-62767406 \\ Email: lujiangyong@gsm.pku.edu.cn
}

\author{
Xiaohui Liu \\ School of Business and Economics, Loughborough University \\ Leicestershire LE11 3TU \\ Tel: 44-01509223349 \\ Email: X.Liu2@lboro.ac.uk
}

\author{
Xiru Zhang \\ Guanghua School of Management, Peking University \\ No. 5 Yiheyuan Road, Beijing, 100871 \\ Tel: 86-13811461917 \\ Email: zhangxiru@gsm.pku.edu.cn
}

Short running title: Returnees’ entrepreneurial decisions

${ }^{1}$ Corresponding author: Jiangyong Lu 


\title{
International knowledge brokerage and returnees’ entrepreneurial decisions
}

\begin{abstract}
Based on the knowledge brokerage literature and the international entrepreneurship literature, we investigate whether returnees' international knowledge transfer affects their entrepreneurial decisions and the extent to which this relationship is contingent on perceived supportive policies for returnee entrepreneurship and returnees’ difficulties with cross-cultural readjustment in their home countries. Analyzing first-hand survey data, we find a positive relationship between international knowledge transfer and returnees' decisions to become entrepreneurs. This positive relationship is strengthened by the perception of the home country's supportive policies for returnee entrepreneurship but is weakened by returnees' perceived difficulties in readjusting to the local norms and culture in their home countries.
\end{abstract}

Keywords: Knowledge transfer, Entrepreneurship in emerging markets, Institutional context, International knowledge brokerage, Returnees, Entrepreneurial decisions 


\section{INTRODUCTION}

Returnees, defined as individuals who have studied and/or worked in foreign countries for a substantial period of time after graduation and then returned to their home countries (Saxenian, 2005) ${ }^{1}$, have been recognized as an important channel for international knowledge diffusion beyond the traditional vehicles of trade and foreign direct investment (Oettl \& Agrawal, 2008). This trend of international human mobility is particularly important for developing countries, which have suffered a "brain drain" in the past but are now benefiting from a "brain circulation" of returnees who have accumulated advanced technological knowledge and business practices in developed countries (Liu, Lu, Filatotchev, Buck, \& Wright, 2010).

Some of these returnees establish their own businesses after their return and become entrepreneurs, playing pivotal roles in economic growth, especially for the rise and development of high-tech industries in their home countries (Kenney, Breznitz, \& Murphree, 2012). Studies have demonstrated important impacts of returnee entrepreneurs on firm-level outcomes such as innovation, exports and financial performance (Filatotchev, Liu, Buck, \& Wright, 2009; Li, Zhang, Li, Zhou, \& Zhang, 2012). However, few studies have examined the antecedents of returnees' entrepreneurial decisions in the first place, which refers more specifically to the decision to pursue entrepreneurial opportunities and become entrepreneurs (Minniti, 2004; Shepherd, Williams, \& Patzelt, 2015). We have limited understanding of what drives returnee entrepreneurship. This is an important knowledge gap because returnees with advanced technical and business knowledge constitute an essential supply of entrepreneurial talent that drives high-tech industry growth (Qin \& Estrin, 2015; Wright, Liu, Buck, \& Filatotchev, 2008) and offsets the lack of local entrepreneurial expertise in emerging markets for high-tech entrepreneurship (Agarwal, Audretsch, \& Sarkar, 2007; Stenholm, Acs, \& Wuebker, 2013). Moreover, examining the factors affecting the identification of entrepreneurial opportunities and the decision to pursue such opportunities is understood to be a central question in international entrepreneurship and deserves more academic attention (Choi \& Shepherd, 2004; Ellis, 2011; Oviatt \& McDougall, 2005). Thus, it is theoretically and empirically important to unpack what motivates returnees to decide to become entrepreneurs. 
Although returnees' role as international knowledge brokers has been explored in intra-firm knowledge transfer within multinational enterprises (MNEs) (Barner-Rasmussen, Ehrnrooth, Koveshnikov, \& Mäkelä, 2014; Oddou, Osland, \& Blakeney, 2009; Lazarova \& Cerdin, 2007), few studies have extended beyond intra-firm knowledge transfer within MNEs (e.g., by repatriates) and considered international knowledge brokerage as an antecedent of international entrepreneurship. It is widely recognized that knowledge transfer involves "recontextualization", that is, the process by which knowledge is seen through new eyes and takes on distinct meanings in new cultural contexts. Through recontextualization, transferred knowledge will be interpreted and applied in ways that differ from its original context (Brannen, 2004; Oddou et al., 2009). This implies that returnees' advantages in knowledge transfer may not be fully utilized due to institutional or cultural differences across countries (Black, Gregersen, \& Mendenhall, 1992; Li et al., 2012). However, we know little about whether international knowledge transfer enhances the probability that returnees will decide to become entrepreneurs after return and what roles the perceived policy support and cross-cultural readjustment difficulties play in such decisions (Agarwal, Echambadi, Franco, \& Sarkar, 2004; McMullen \& Shepherd, 2006). In particular, research on the tension between the advantages of returnees' knowledge transfer and challenges associated with recontextualization is absent. To address this issue, we examine the following research question: Under what conditions are returnees more likely to make the entrepreneurial decision and become entrepreneurs?

Based on the knowledge brokerage literature and the international entrepreneurship literature, our study demonstrates a positive relationship between international knowledge transfer and returnees' entrepreneurial decisions. It also demonstrates the contingent effects of returnees' perceived policy support in the home country and their perceived cross-cultural readjustment difficulties. Thus, we make a number of contributions to the existing literature. First, unlike previous research that has focused exclusively on the impacts of returnee entrepreneurs on firm performance (Qin \& Estrin, 2015), our study investigates the factors influencing returnee entrepreneurship. By examining the heterogeneity in knowledge transfer within the returnee group, our study highlights the role of international knowledge brokerage in affecting returnees' entrepreneurial decisions. In so doing, we expand the boundary of international entrepreneurship by linking returnees' brokerage advantage with 
their entrepreneurial decisions, thus enriching our understanding of international entrepreneurship by reflecting the increasing human mobility across national borders. Second, our research extends the international knowledge brokerage literature by going beyond the widely recognized role of knowledge brokers in knowledge transfer within MNEs (Barner-Rasmussen et al., 2014). We propose that international knowledge brokerage can also motivate returnee brokers to make entrepreneurial decisions in the home country, thus linking the brokerage literature with the international entrepreneurship literature. Finally, despite the benefits associated with international knowledge brokerage in deciding to pursue entrepreneurial opportunities, we take account of returnees' perceptions of the support offered or challenges posed by formal and informal institutions that influence their entrepreneurial decisions. By delineating the contingent effect of perceived institutional support from home countries and cross-cultural readjustment difficulties, our study contributes to a more complete understanding of not only the benefits but also the challenges associated with leveraging international knowledge brokerage in making entrepreneurial decisions.

\section{THEORETICAL BACKGROUND AND HYPOTHESES}

Individuals who transfer knowledge across national borders are recognized as international knowledge brokers (Reiche, Harzing, \& Kraimer, 2009; Wang, 2015). Knowledge brokerage is derived from the theory of structural holes, which states that certain firms or individuals play a key role in bridging knowledge gaps and generating access among previously unconnected knowledge resources (Burt, 1992). It has been found that brokers who are familiar with activities in different regions/countries are better able to see how knowledge or practices in one region could create value in the other and then translate the knowledge or practices into business opportunities in the target region (Bae, Wezel, \& Koo, 2011; Burt, 2004). In particular, knowledge brokers have advantages in accessing valuable information prior to others, and they enjoy benefits in terms of exerting controls over rewarding opportunities, which are referred to as information and control benefits (Burt, 1992). Information benefits are derived from the brokerage position, which enables brokers to have timely access to valuable information, referrals and resources. Control benefits are associated with the fact that disconnected parties may be dependent on a broker to gain access to valuable opportunities, which 
gives the broker advantages in negotiating favorable terms to extract payment from or make future claims on these parties. Given the knowledge disparity between the developed host countries and the developing home countries in terms of technological development and business practices, returnees who transfer advanced knowledge from overseas may act as knowledge brokers and may have information and control benefits that prompt them to make entrepreneurial decisions and pursue potential entrepreneurial opportunities by bridging cross-border knowledge gaps.

However, overseas knowledge is embedded in origin countries, and vigilance and effort are required to translate and adapt it to other countries (Oddou et al., 2009). Despite the advantages of international knowledge brokerage, transferring new knowledge from developed countries to developing countries is associated with uncertainty because recontextualizing knowledge originating from developed countries requires complementary assets (Krueger, 2000; Shane \& Venkataraman, 2000; Simon, Houghton, \& Aquino, 2000). Thus, the effectiveness of international knowledge transfer is contingent on institutional factors that may hinder or facilitate the acquisition of complementary assets (Batjargal, Hitt, Tsui, Arregle, Webb, \& Miller, 2013; Caligiuri, 2014; Vasudeva, Zaheer, \& Hernandez, 2013). Research has shown that a cooperative relationship with the local government in developing countries assists knowledge brokers in acquiring complementary resources and external legitimacy (Luo, 2001; Spencer, 2003). In contrast, brokerage advantages are less effective in countries with institutional voids or with a dominant spirit of interpersonal trust, because the lack of efficient formal institutions and a collectivist culture impedes brokers from gaining the necessary resources to capture the value of international knowledge (Guler \& Guillen, 2010; Stam, Arzlanian, and Elfring, 2014; Xiao \& Tsui, 2007). Therefore, international knowledge transfer by returnees through entrepreneurial activities also depends on the recontextualization of overseas knowledge due to cross-country variations in institutional environments.

Potential entrepreneurs tend to conceive of exploiting opportunities and assess uncertainties and risks (Shane \& Venkataraman, 2000; Simon et al., 2000) when making an entrepreneurial decision, which is central to the entrepreneurial intentions for action (Krueger, 2000). Given the lack of well-established formal institutions and the returnees' lack of network density, shared understanding and common identity in the home country (Li et al., 2012; Rowley, Behrens, \& Krackhardt, 2000), 
returnee knowledge brokers may evaluate the beneficial or adverse influence of the formal and informal institutional environment (Choi \& Shepherd, 2004; McMullen \& Shepherd, 2006), which will determine resource allocation and the rules of the game in their home countries. Therefore, we study not only the relationship between international knowledge brokerage and returnees' entrepreneurial decisions but also the contingent effects of perceived support or challenges in the institutional environment.

\section{International Knowledge Brokerage and Returnee Entrepreneurship}

Although returnees share some common features, such as knowledge about their host countries, they are a heterogeneous group, varying in terms of skills and engagement in international knowledge flows (Liu et al., 2010). Some returnees have learned technical expertise in the host countries and are returning to facilitate the development of high-tech industries in the home country (Agrawal, Kapur, McHale, \& Oettl, 2011). Others have learned new business ideas and obtained advanced management practices and skills due to their exposure to various business environments abroad, and they bring back advanced business knowledge (Levin \& Barnard, 2013). Their roles as knowledge brokers grant them information and control benefits, thus giving them advantages in pursuing rewarding opportunities. To account for a general situation of knowledge transfer, we propose that returnees transferring either technological knowledge or business knowledge from their host countries to their home countries are more likely to make entrepreneurial decisions than those who do not transfer knowledge at all (Agarwal et al., 2004; Burt, 1992; Long \& Ismail, 2011). There are two main reasons for this based on the brokerage literature.

First, returnee knowledge brokers enjoy the benefits of information arbitrage in the pursuit of entrepreneurial opportunities. Information benefits have been defined in terms of gaps or structural holes separating people with similar knowledge and resources (Burt, 1992). Returnees who transfer advanced knowledge are typically experienced in a specific domain and connected to both their host countries and their home countries (Liu et al., 2010; Wang, 2015). Given that those linked within social clusters (i.e., a country) tend to know what others in the same cluster know, returnee knowledge brokers who bridge their host and home countries could be a conduit for disseminating information 
about entrepreneurial opportunities (Burt, 1992). It has been found that individuals who span different countries are more likely to identify opportunities via timely access to non-redundant information (Ellis, 2011). For example, R\&D collaborations between distant geographic areas give rise to the establishment of new firms due to access to novel and diverse knowledge (Bae et al., 2011). Because the source of entrepreneurial opportunities is rooted in information asymmetries (Eckhardt \& Shane, 2003), returnee knowledge brokers have advantages in pursuing entrepreneurial opportunities due to better access to a broad array of novel and non-redundant ideas by spanning countries (Burt, 2004; Ellis, 2011).

Second, returnee knowledge brokers are in a better position to pursue entrepreneurial opportunities by exerting control over the international knowledge gaps. Due to the wide-ranging disparity in resource endowments, technology development and path-dependent trajectories between countries, technological knowledge and managerial practices from the developed countries typically lead to entrepreneurial opportunities in the home countries (Baker, Gedajlovic, \& Lubatki, 2005; Drucker, 1985; Eckhardt \& Shane, 2003). Because there is uncertainty about the preferences, demands and comparable resources between actors from the two disconnected countries, brokers who mediate the information can exercise control by determining who could be engaged in a negotiation and bargaining for favorable terms to pursue an opportunity (Burt, 1992). Returnee knowledge brokers have experience and expertise about the specific domains in both countries and thus have advantages in understanding the resources and preferences being played against one another by actors from the host and home countries. By leveraging the information advantages of their brokerage positions, returnees can occupy an essential position in pursuing the opportunity by exerting control over the new knowledge and the negotiation associated with filling international knowledge gaps.

In summary, returnee knowledge brokers’ engagement in international knowledge transfer (either technological knowledge or business knowledge transfer) enables them to identify and pursue entrepreneurial opportunities through information arbitrage and exercising control over the knowledge gaps. As Burt (1992: 48) has observed, "the information and control benefits are multiplicative, augmenting and dependent on one another, together emerging from the wellspring of structural holes in a network.” Having timely access to novel information facilitates control over the international 
knowledge gaps, and exerting control over the gaps elicits additional information from contacts that can help fill the knowledge gaps. With information and control benefits augmenting one another, returnee knowledge brokers are more likely to have advantages in bridging the international knowledge gaps, thus increasing their desire to pursue the entrepreneurial opportunity. Therefore, we propose the following hypothesis:

Hypothesis 1: Returnees who have brought back advanced knowledge from their host countries to their home countries are more likely to decide to become entrepreneurs than those who have not done so following their return to their home countries.

\section{Contingent Factors of Returnee Entrepreneurship}

Despite the benefits stemming from knowledge brokerage that facilitate the pursuit of entrepreneurial opportunities, the effect of brokerage advantages may be contingent on returnees' perception of the institutional environment in terms of policy support and cultural readjustment (Batjargal et al., 2013; Vasudeva et al., 2013; Xiao \& Tsui, 2007). In other words, returnee knowledge brokers must evaluate the accessibility of resources and capabilities in their home country that is necessary for effective exploitation of entrepreneurial opportunities (Haynie, Shepherd, \& McMullen, 2009). Thus, we argue that the perceived support or challenges in the formal and informal institutional environment will influence returnee knowledge brokers’ decision to pursue entrepreneurial opportunities.

In developing countries with less-established formal institutions, governments typically serve as resource allocators that provide critical assets (Li \& Atuahene-Gima, 2001). To attract more talent for economic growth, governments in developing countries have devised polices to support returnee entrepreneurship. The perceived support from the government may ease returnees' perception of the constraints caused by a lack of complementary resources and motivate them to exploit brokerage advantages through entrepreneurial activities. Moreover, informal institutions, such as social norms and the rules of the game, determine the process of gaining legitimacy and play pivotal roles in obtaining complementary resources (Luo, 2001). Because returnees have been acculturated to the developed host country environment and have faced difficulty in readjusting to the culture and norms in the developing home country (Furuya, Stevens, Bird, Oddou, \& Mendenhall, 2009), their 
perceptions of readjustment difficulties may heighten their concern about the uncertainty associated with recontextualizing overseas knowledge at home. Hence, we regard the perceived benefits of home country policy support and cross-cultural readjustment difficulties as contingent factors that influence returnees' entrepreneurial decisions.

Perceived policy support for returnee entrepreneurship. Returnee knowledge brokers must overcome institutional differences to realize brokerage advantages through entrepreneurial activities. While developed countries have well-established systems, such as regulations, sufficient infrastructures and specialized complementary resources to support the creation and diffusion of advanced knowledge, developing countries typically lack well-established regulatory systems and infrastructure development that are necessary to pursue entrepreneurial opportunities through international knowledge transfer.

To compensate for the underdeveloped institutions, governments in some developing countries have launched supportive policies to attract returnees with advanced overseas knowledge through various programs. For example, the central and local governments in China have launched a series of initiatives since the late 1990s, such as "Recruitment Program of Global Experts (Thousand Talents Program)", "Beijing Clustering Program of Global Talents (Beijing Haiju Program)”, and "Zhongguancun Science Park Clustering Program of Leading Talents (ZSP Gaoju Program)”. Supportive policies usually include the following: direct funding for returnee enterprises and their R\&D projects to facilitate returnee firms' early development and technology innovation; exemption of tax and rent to help them survive; support for cross-border transactions such as an importing apparatus; and referrals and endorsement for returnee firms' resource acquisition ${ }^{2}$. These supportive policies compensate for the typical market failures in creating/transferring new knowledge, and they help avoid early exodus and a high frequency of new business failures, given the high uncertainty and risks inherited in new firm formation (Falk, 2007; Shane \& Venkataraman, 2000).

Returnees may assess the extent to which they will be supported by the home country government for entrepreneurial activities. This is especially important for returnees who bring back advanced knowledge to the home country because the newness of the knowledge increases the uncertainty over its utilization in a different context and places a greater strain on the resources necessary for successful 
exploitation (Sapienza \& Gupta, 1994). Perceived policy support for returnee entrepreneurship in the home country can facilitate returnees' entrepreneurial decisions in two aspects: one is that increasing the perceived available resources from the government, including financial and physical resources, may help ease returnees’ concerns about resource acquisition in pursuing entrepreneurial opportunities. Specifically, with the funding, exemption and rent-free offices provided by the government, the perceived uncertainty and risks associated with transferring new knowledge to a different context may be reduced. The other is to provide referrals and endorsement for nascent entrepreneurs to gain support from third parties (e.g., venture capital, banks, human resources). Because returnee brokers usually lack local connections, endorsement from the government may help them build legitimacy and signal their credibility in the eyes of resource holders in the home country, thus facilitating resource acquisition. Given the benefits provided by home country government policies in acquiring complementary resources and gaining legitimacy, perceived policy support from the home country's government helps overcome the constraints associated with cross-country institutional barriers and improves returnees' assessments of accessible resources (Choi \& Shepherd, 2004; Falk, 2007; Kraimer \& Wayne, 2004). Therefore, perceived policy support increases the likelihood that returnees who engage in international knowledge transfer will decide to pursue entrepreneurial opportunities in the home countries. Thus, we propose the following hypothesis:

Hypothesis 2: Perceived policy support for returnee entrepreneurship strengthens the relationship between international knowledge transfer and returnees'entrepreneurial decisions.

Perceived cross-cultural readjustment difficulties. Returnees may encounter "reverse cultural shocks” and may need to readjust to the local environment. This is because they may have adopted the social norms of their host countries, and/or the social norms in their home countries may have changed during their absence (Black et al., 1992). Because social norms and culture influence the way of conducting business and the acquisition of cognitive and moral legitimacy (Bruton, Ahlstrom, \& Li, 2010), the extent to which returnees perceive difficulties in re-adapting to local norms and culture in their home countries affects their ability to gain external legitimacy and acquire complementary resources. 
Returnees' decision to pursue an entrepreneurial opportunity depends on their evaluation of the uncertainty and risks associated with international knowledge transfer. The transfer of advanced knowledge to developing countries entails high uncertainty and requires complementary resources that depend on the socialization process and cultural legitimacy, such as communication, trust and shared understanding (Reiche et al., 2009). Therefore, cross-cultural readjustment difficulties are particularly challenging for returnee knowledge brokers, given that knowledge generated in developed host countries is context-specific and subject to norms, policies, and processes that are different from those in the home countries (Oddou et al., 2009). Returnee knowledge brokers must show how new ideas or a set of competencies in one country have the potential for value creation or can be applied in a novel way in another country. While perceived policy support helps knowledge brokers acquire complementary resources and gain legitimacy in their home country, perceived readjustment difficulties hinder returnees' communication with potential resource holders, thus posing challenges to acquiring complementary resources to commercialize international knowledge. Therefore, the perceived readjustment difficulties may heighten returnees' concerns about the uncertainty of exploiting brokerage advantages through entrepreneurial activities in their home country or the extent to which advanced knowledge can be translated into entrepreneurial opportunities in their home countries. We propose that perceived difficulties in readjustment to local norms and culture may deteriorate the returnee knowledge brokers' evaluation about gaining the legitimacy and complementary resources necessary for knowledge transfer, thus hindering them from making decisions to pursue entrepreneurial opportunities.

Hypothesis 3: Perceived cross-cultural readjustment difficulties weaken the relationship between international knowledge transfer and returnees'entrepreneurial decisions.

\section{DATAAND METHODOLOGY}

\section{Data Collection}

China has experienced the "brain circulation" phenomenon on a large scale in recent years; thus, it is an ideal context for a study of returnee entrepreneurship ${ }^{3}$. The survey data used in this study were 
collected from participants in the Guangzhou Convention of Overseas Chinese Scholars in Science and Technology in December 2011. The convention has been held in Guangzhou every year since 1998 and has grown into the largest platform for Chinese returnees to search for jobs, venture investments and cooperation opportunities from all over China. It provides a proper research setting for collecting data on the factors that influence returnees' entrepreneurial decisions. In collaboration with the organizers of the convention, we obtained a list of 2612 returnees who registered to attend the convention in 2011, including their contact information and other basic background data, such as gender, fields of study and host countries.

Our questionnaire was first developed in Chinese and then translated into English and back-translated into Chinese with assistance from independent translators to ensure conceptual equivalence (Hoskisson, Eden, Lau, \& Wright, 2000). A pilot study was carried out with four returnees who had overseas educational backgrounds and were planning to start their own businesses or to find jobs in China. Each was asked to complete the questionnaire and identify any unclear questions. We modified the questionnaire according to their feedback.

We sent emails to the 2612 registered returnees to invite them to participate in the online survey. To encourage them to respond, we promised to send the respondents a book on returnees written by one of the study authors and a research report based on the survey. The online survey was open from December 2011 to February 2012. We sent four rounds of invitations to the returnees on our list during this period. In each round of follow-up invitations, we excluded the returnees who had already participated in the survey from the email list. A total of 264 questionnaires were received (a 10.1\% response rate), and 217 surveys were retained after we screened and deleted questionnaires with missing data. The possibility of non-response bias was checked by comparing the personal profiles of the respondents with those of the non-respondents. The calculated t-statistics for gender, overseas education, fields of study and host countries were all statistically nonsignificant, indicating that there were no significant differences between the respondents and non-respondents. To further explore and illustrate the mechanism of how international knowledge transfer affects returnees' entrepreneurial decisions, we conducted follow-up interviews and an additional analysis to complement the statistical analysis of the survey data (Creswell, 2013). 


\section{Measures}

Dependent variable. The dependent variable, Returnees' entrepreneurial decisions, refers to their decision to pursue entrepreneurial opportunities and become entrepreneurs after they return to their home countries (Minniti, 2004; Shepherd et al., 2015). The variable was measured with a dummy variable based on the following question: "Have you decided to start your own business?" This question captures the conceptual meaning of our construct in that it reflects the returnees' decision to pursue entrepreneurial opportunities rather than enter the job market after they return to their home countries.

Independent variable. The key independent variable, International knowledge transfer, refers to whether a returnee has brought knowledge that is advanced in China back from his/her host country. Returnees can bring back technologies and knowledge about how business should be conducted, both of which can result in opportunity identification and new firm formation (Agarwal et al., 2004; Huber, 2013). Previous studies have found that returnees, either through patents or transferring advanced business models from the host countries to the home countries, are more likely to identify and pursue an entrepreneurial opportunity, including high-tech-related opportunities (Huber, 2013; Riddle \& Brinkerhoff, 2011; Wright et al., 2008). Following previous studies, we regarded bringing back either technological knowledge or business knowledge as international knowledge transfer. We created a dummy variable based on the following two questions: "Have you brought back advanced technological knowledge that is new for China from your host country?" and "Have you brought back advanced business knowledge (i.e., business model) that is new for China from your host country?” If either question was answered "yes", the variable was coded as "1"; otherwise, it was coded as "0". This variable enables us to test whether either type of knowledge transfer is more likely to lead to entrepreneurial activities compared with the baseline of no knowledge transfer. We further explore the three different scenarios of knowledge transfer in additional analyses.

Moderators. Following Hinkin (1998), we used an inductive approach to generate items for the two moderators: perceived policy support for returnee entrepreneurship and perceived readjustment difficulties of returnees. We first consulted the literature to identify important theoretical dimensions 
for policy support and readjustment difficulties and then conducted interviews with returnees to collect contextual information on the two moderators. The interviewer took notes and reiterated the interviewees' comments to verify their actual meaning during the interviews and to categorize policy support and readjustment difficulties into several dimensions.

Perceived policy support for returnee entrepreneurship. Because policies for attracting returnee entrepreneurs are context specific and because the literature has presented a limited number of measurements, we reviewed the documents of government policies for returnee entrepreneurs and conducted interviews to aid the development of measures. We evaluated returnees' perceptions of governmental policy support for returnee entrepreneurship by asking them to specify one or more aspects of such policy support that they knew about or actually benefited from.

We classified the answers into four categories based on the interviews. The first category is support for technological projects, including equipment and funds. The second category involves direct financial support, namely, capital support, reduced rents for several years in the initial stage of venturing, and other exemptions. The third category concerns government endorsements, including support for loans and financial resource acquisition. The fourth category consists of tax reductions for overseas importing. We further checked the policies issued by various levels of Chinese governments to ensure we had covered important dimensions in policy support for returnee entrepreneurship. Therefore, the refined four items measured the extent to which returnees perceive that government policies (1) support technology development projects led by returnees, (2) provide a wide range of funding for returnee-founded enterprises, (3) support returnee entrepreneurs' loan applications, and (4) impose fewer restrictions on importing technological apparatuses by returnee enterprises. The items were rated on a scale ranging from 1 (strongly disagree) to 7 (strongly agree) ${ }^{4}$. We conducted an exploratory factor analysis (EFA). The results indicated a one-factor solution with all loadings at 0.78 or higher.

Perceived readjustment difficulties of returnees. Similarly, to develop the context-sensitive measure of returnees' perceived readjustment difficulties, we relied on interviews to generate scale items. We asked returnees to indicate their experiences of readapting to the social norms and local culture in China. 
Based on the information collected in the interviews, we developed four items to measure the extent to which they perceived difficulties in the following areas: (1) returnees' management orientations do not work in China; (2) returnees' behavioral patterns do not match the way of conducting business in China; (3) returnees do not understand the rules of the game in China; and (4) returnees' beliefs from Western culture conflict with Chinese culture. These items were also rated on a scale ranging from 1 (strongly disagree) to 7 (strongly agree). The EFA results indicated a one-factor solution, with all loadings at 0.71 or higher.

We also conducted confirmatory factor analysis (CFA) to examine the discriminant validity of the two moderator variables. The Cronbach's alphas of perceived Policy support for returnee entrepreneurship and Readjustment difficulties of returnees are 0.87 and 0.75 , respectively. The fit indices from a CFA model (RMSEA=0.05, CFI=0.98, NFI=0.96) indicate that the hypothesized two-factor structure fits the data well. We also estimated a one-factor model (all eight items loading onto the same factor) to assess more-parsimonious models. We conducted a chi-squire difference test and found that the two-factor model has a significantly better fit to the data $(\mathrm{p}<0.001)$. This analysis provides statistical support for construct validity (Table 1).

\section{/*Table 1 goes about here*/}

Control variables. To account for other possible determinants of returnees' entrepreneurial decisions, we controlled for returnees' characteristics, human capital, the environments of the host countries and home country regions, and industries. First, following previous research (Lim, Morse, Mitchell, \& Seawright, 2010), we controlled for returnees' demographic characteristics (e.g., gender and age) and personal traits. Gender was measured as a binary variable, with male respondents assigned a value of " 1 " and female respondents assigned a value of "0". Age at return was measured as the logarithm of returnees' age following return. Overseas duration was measured as the logarithm of returnees' overseas duration (years). We also controlled for the Number of host countries where the returnees studied and/or worked. Moreover, as previous research on entrepreneurship suggests, individuals' personal traits and career motives may directly influence their predilection for entrepreneurship (Gabrielsson \& Politis, 2011). To capture individual differences in internal career 
orientation toward becoming an entrepreneur, we controlled for the returnees' Entrepreneurial attributes based on the scales developed by Dyer, Gregersen, and Christensen (2008) (Cronbach's alpha $=0.91$ ). These scales distinguish the behavioral attributes of entrepreneurs, including asking questions frequently, engaging in active observation, experimenting and exploring frequently, and utilizing a network to discuss new ideas. Individuals with more entrepreneurial attributes may demonstrate a greater desire for novelty and thus be more likely to have a career preference for entrepreneurship.

Second, we controlled for returnees' human capital accumulated overseas. Previous studies have demonstrated a strong relationship between human capital and entrepreneurship (Davidsson \& Honig, 2003). We coded the highest academic degrees that returnees obtained overseas and generated a dummy variable, Overseas doctoral degree, which compares returnees who have overseas doctoral degrees or post-doctoral research experience with those who do not have such degrees or experience. We also measured Overseas work experience as the years that returnees had worked in their host countries. Then, we logged the "overseas working years+1" to match a normative distribution. In addition, we measured Overseas entrepreneurship experience with a dummy variable, which was assigned a value of " 1 " if the respondent had started a business overseas and a value of "0" otherwise. Finally, we controlled for Major in sciences or engineering as a binary variable because previous research has suggested that education specialty reflects an individual's cognitive style and personality and thus influences the identification of business opportunities (Gruber, MacMillan, \& Thompson, 2012). The variable was measured with a value of " 1 " if the respondent majored in sciences or engineering for their highest degree and a value of " 0 " if the respondent majored in arts or social sciences.

Third, because research has shown that the institutional environments of host countries influence returnees' advantages that were accumulated overseas, we controlled for economic conditions in the host countries and generated the dummy variable Developed host country following the World Bank's categorization of developed countries. Returnees from developed host countries may have greater access to advanced knowledge and information and, thus, are more likely to decide to be entrepreneurs. Institutions in home countries also influence entrepreneurial activities. The economic development and 
institutional environment in different regions of China differ markedly and greatly influence the rate of entrepreneurship. Thus, we categorized the provinces in which the returnees plan to start their businesses or careers following their return to four regions: the Pearl River Delta Region, the Yangtze River Delta Region, the Beijing-Tianjin Region and other regions. These were labeled as Home country location dummies. A few additional dimensions related to facilitating returnees’ personal lives and family were also taken into account. Given that government support for returnees' personal lives and family may influence their readjustment in the home country, we also controlled for Policy support for returnee family, which was measured based on three items: the extent to which the government (1) provides support for the education of returnees' children, (2) relaxes the restriction concerning the household registration system for returnees, and (3) provides financial support for returnees’ housing. These items were rated from 1 (strongly disagree) to 7 (strongly agree).

Finally, we controlled for industry variations. We categorized the industries in which the returnees plan to start their businesses or careers following their return into a dummy variable, Strategic emerging industry, which was assigned a value of " 1 " if the industry belongs to the seven national strategic emerging industries ${ }^{5}$ according to the 12th Five-Year Plan Outline ${ }^{6}$ and a value of “0” otherwise.

\section{Model}

Logistic regression was used to analyze returnees' entrepreneurial decisions concerning whether to become entrepreneurs. The predicted proportion of activities follows the logistic model of $\ln P /\left(1-P_{i}\right)=$ $\beta X_{i}$, where $P_{i}$ is the probability of deciding to be an entrepreneur. Because the effect size represents the economic significance, as opposed to the statistical significance of the results (Ellis, 2010), we also reported the effect size indices and their interpretation using STATA Margins commands (Williams, 2012).

Moreover, as the coefficients of interactions in nonlinear models do not necessarily represent the sign, statistical significance and magnitude of conditional effects (Zelner, 2009), we used the Marginsplot command introduced in STATA Version 12 to plot graphical displays of the interaction effects. This approach visually compares predicted probabilities associated with different 
combinations of independent variable values and tests whether the difference in predicted probabilities is significantly different from zero by constructing a confidence interval (Mitchell, 2012). We interpreted the statistical and economic significances of the direct effects (H1) based on the coefficient and discussed the hypothesized moderation effects (H2 and $\mathrm{H} 3$ ) based on figures using the Marginsplot command.

\section{RESULTS}

We took several steps to minimize the effect of common method variance (CMV). First, we improved the scale items by using multiple item constructs and different scale formats for predictor and criterion measures to diminish method biases (Podsakoff, MacKenzie, Lee, \& Podsakoff, 2003). In addition, we counterbalanced the question order in the survey by placing the dependent variable before the independent variables, which can neutralize some of the method biases that affect the retrieval stage by controlling the retrieval cues prompted by the question context (Podsakoff \& Organ, 1986). Furthermore, we used a nonlinear regression model with interaction terms, which can reduce the likelihood of CMV because respondents are unlikely to be guided by a cognitive map that includes difficult-to-visualize interaction and nonlinear effects (Chang, van Witteloostuijn, \& Eden, 2010). Finally, following Harman's single-factor test, we conducted a CFA with all the variables used in our study to examine whether a single factor can account for all the variance in the data. The results showed that a single factor model does not fit the data well (CFI=0.08; RMSEA=0.11). We also performed an EFA with all the variables, which yielded five factors with eigenvalues greater than one, explaining $56.0 \%$ of the total variance. The largest factor explains only $22.5 \%$ of the variance. The test results suggest that CMV does not pose a serious problem in this study.

Table 2 presents the means, standard deviations and correlations of the variables. It can be seen that international knowledge transfer is significantly correlated with returnees' entrepreneurial decisions. On average, returnees in the sample spent almost ten years in over two host counties. Nearly $56 \%$ of returnees obtained a doctoral degree abroad and had 4.67 years of overseas work experience. In addition, $29 \%$ of them started their own business during their stay overseas. The variance inflation factor (VIF) for each variable is less than two, which shows that the degree of multicollinearity is low. 


\section{/*Table 2 goes about here*/}

Table 3 presents the main logistic regression results. Model 1, which includes only the control variables, shows some interesting findings. Returnees’ demographic characteristics are related to their decision to enter entrepreneurship. Those returning to the home country at an older age, with shorter overseas duration and with stronger entrepreneurial attributes have a higher probability of deciding to become entrepreneurs ( $r=3.20, \mathrm{p}=0.03$; $r=-1.06, \mathrm{p}=0.09$; and $\mathrm{r}=0.92, \mathrm{p}=0.05$, respectively). Returnees' human capital also influences their probability of becoming entrepreneurs. Overseas work experience and overseas entrepreneurial experience are positively related to returnees' entrepreneurial decisions ( $r=1.12, p=0.04$ and $r=1.95, p=0.001$, respectively). Finally, those returning from developed host countries and who plan to start their careers in one of the seven strategic emerging industries authorized by the Chinese government have a higher probability of deciding to become entrepreneurs (r=1.09, $\mathrm{p}=0.02 ; \mathrm{r}=2.86, \mathrm{p}=0.001$, respectively).

\section{/*Table 3 goes about here*/}

Model 2 shows that returnees who transfer advanced knowledge (either technological or business knowledge) from their host countries to their home countries have a $20.5 \%$ higher probability of deciding to become entrepreneurs $(\mathrm{r}=0.63, \mathrm{p}=0.004)$ than those who do not transfer advanced knowledge. The statistical and economic significance of the results support H1.

Models 3 and 4 test the moderation effects of perceived policy support for returnee entrepreneurship and perceived readjustment difficulties of returnees, as proposed in H2 and H3. Because the magnitude or the statistical significance of interaction effects cannot be directly discerned from the raw coefficient estimates and standard errors in nonlinear logit models (Zelner, 2009), we relied on plotting figures to present the differences in predicted probabilities associated with discrete changes in the moderators.

Figure 1 presents the interaction effect of international knowledge transfer and perceived policy support for returnee entrepreneurship based on Model 3 of Table 3. It highlights the statistical and economic significance of the difference in predicted probabilities of entrepreneurial decisions for 
returnees with and without international knowledge transfer. It shows that the moderation effect is statistically significant when the factor score of perceived policy support for returnee entrepreneurship is above -0.5 ( $76 \%$ of the observations). The difference in the predicted probabilities of deciding to become an entrepreneur increases from $21 \%$ to $31 \%$ when perceived policy support for returnee entrepreneurship increases by one standard deviation. The results shown in Figure 1 are statistically and economically significant and, thus, support $\mathrm{H} 2$.

\section{/*Figure 1 goes about here*/}

Figure 2 is generated based on Model 4 of Table 3 and presents the interaction effect of international knowledge transfer and the perceived readjustment difficulties of returnees. It reveals that the moderation effect is statistically significant when the factor score of perceived readjustment difficulties of returnees is below 0.3 (60\% of the observations). Regarding the economic significance of the moderation effect, the difference in the predicted probabilities of becoming an entrepreneur decreases from $29 \%$ to $18 \%$ when the returnees' perceived readjustment difficulties increase by one standard deviation. Combining both the statistical results and the economic significance shown in Figure 2, we concluded that H3 is supported.

\section{/*Figure 2 goes about here*/}

To further explore the mechanisms of how international knowledge transfer affects returnees' entrepreneurial decisions, we conducted follow-up interviews with returnee entrepreneurs. According to Creswell (2013), an explanatory sequential mixed methods design can be used to have the qualitative data help explain the initial quantitative results in more detail. The above survey data analysis has shown the relationship between international knowledge transfer and returnees' entrepreneurial decisions. We further collected in-depth qualitative data to reveal how international knowledge transfer facilitates returnees’ entrepreneurial decision.

We sent emails to the returnee entrepreneurs who reported transferring advanced technological knowledge or business knowledge in the survey and invited them to participate in additional telephone 
interviews. Seven returnee entrepreneurs replied with their consensus. We conducted telephone interviews with two open-ended questions regarding (1) what advanced technology or business knowledge the interviewees brought back and (2) how they identified the entrepreneurial opportunities and decided to start their own venture. Each telephone interview was recorded and transcribed. The interview data were coded by two of the authors independently, using standard coding instructions with Nvivo 10, and the inter-coder agreement was 0.81 . The qualitative evidence was coded into categories guided by the brokerage literature: information benefits and control benefits associated with the returnees' brokerage position. The main qualitative evidence is summarized in Table 4.

Based on the interview data, six of the seven interviewees reported bringing back advanced technological knowledge, while two of them reported bringing back business knowledge. Regarding the mechanisms of transfer knowledge affecting returnees’ entrepreneurial decisions, we found that all interviewees voiced that they are aware of knowledge gaps/business opportunities between their host and home countries in a certain specialty due to their experience and expertise. For example, Entrepreneur D stated:

"From my work experience and technology expertise, I know exactly the needs and technology disadvantages of firms in the equipment manufacturing industry (in China). In the U.S., the coverage ratio of 'manufacturing condition monitoring' is about 60 percent. The percentage is much smaller in China. It means that the U.S. finished this development 10 years ago, while China has just begun." (Entrepreneur D)

Beyond their knowledge about the gap between host and home countries, they also have information about the advantages and disadvantages of relevant players (e.g., suppliers, competitors) in the home country. For example, Entrepreneur B stated that:

"We see the great market potential and human resource advantages in China. The large number of university-trained engineering graduates as well as the trend of U.S. automobile firms moving their outsourcing to China makes China an attractive market. However, Chinese firms lack the ability to develop and manufacture core components of the automobile, such as the engine and transmission. We can exploit our advantages in technology and have better development." (Entrepreneur B)

The above qualitative evidence extends our understanding about the information benefits that not 
only help returnee brokers identify international knowledge gaps but also help them understand the market conditions in the home country, which together facilitate the pursuit of entrepreneurial opportunities. In addition to the information benefits associated with international knowledge gaps, we found that returnee brokers can leverage the advanced knowledge to fill the knowledge gap, which makes opportunities more attractive. For example, Entrepreneur A stated that:

"The technology I have mastered is cutting-edge, even in developed countries. There are no more than two factories in the world that can produce this chip. If I can bring this technology back and found a firm, my company will be the third one in the world that can industrialize the gene chip technology." (Entrepreneur A)

Moreover, based on their information benefits, returnee brokers can exert control over the resources associated with the knowledge gaps. They either possess the resources needed to fill the knowledge gap or have information about who has the critical resources and how to gain access to them:

"I have the confidence to accomplish the technology development for my business, even to develop international cutting-edge technology in my field. I was specialized in materials science in a R\&D department in the U.S. Although I may not know much about other sciences such as optics and machines, I know who can do it and have access to the needed technology and resources." (Entrepreneur F)

The above evidence shows that knowledge brokerage grants returnees timely access to diverse information about international knowledge gaps. It also grants them control benefits over the knowledge and resources needed to fill the international knowledge gaps, thus motivating them to pursue entrepreneurial opportunities in order to seek economic rents. Taken together, the findings based on the interviews complement the quantitative evidence and enrich our understanding of the relationship between international knowledge transfer and returnees’ entrepreneurial decisions.

\section{Additional Analyses}

Do types of international knowledge transfer matter? Returnee brokers are heterogeneous and may transfer different types of international knowledge or even a combination of different types of knowledge. Because technological know-how and business-related know-how are complementary in 
facilitating new venture development (Agarwal et al., 2004), we further compare different scenarios of international knowledge transfer by returnees: those who transfer only technological knowledge, those who transfer only business knowledge, and those who transfer both types of knowledge. Three dummy variables, "Transferring only technological knowledge”, “Transferring only business knowledge”, and "Transferring both types of knowledge", are created to compare the three scenarios with the baseline category: "without international knowledge transfer". The results of the comparison are shown in Appendix $1^{7}$.

First, we compare the differences between transferring only technological knowledge and transferring only business knowledge. The comparison shows that, compared with no international knowledge transfer, returnees who transfer only technological knowledge are more likely to make entrepreneurial decisions, while transferring only business knowledge does not show the same effect. The results suggest that returnees who transfer technological knowledge may be more able to capitalize on technological gaps between home and host countries through pursuing entrepreneurial activities. As for the moderating effects, we found that perceived policy support for returnee entrepreneurship and perceived readjustment difficulties of returnees only moderate the relationship between transferring technological knowledge and returnees' entrepreneurial decisions, not the relationship between transferring business knowledge and returnees’ entrepreneurial decisions.

Second, we compare the differences between transferring a combination of technological and business knowledge and transferring only one type of knowledge (transferring only technological knowledge or transferring only business knowledge). The logistic regression results show that compared with no international knowledge transfer, transferring both types of knowledge has significant effects on returnees’ entrepreneurial decisions. By conducting a one-degree-of-freedom test comparing the means, we find that returnees transferring both types of knowledge have significantly higher probabilities of making entrepreneurial decisions than those transferring only technological knowledge or transferring only business knowledge $(\mathrm{p}=0.08$ and $\mathrm{p}=0.01)$. Perceived policy support for returnee entrepreneurship and perceived readjustment difficulties of returnees significantly moderate the relationship between transferring both types of knowledge and returnees' entrepreneurial decisions. Compared with transferring only technological knowledge or business knowledge, transferring both 
types of knowledge is more contingent on perceived policy support and perceived readjustment difficulties.

Overall, the additional analysis shows that transferring a combination of technological and business knowledge contributes to higher probabilities of making entrepreneurial decisions than transferring only one type of knowledge, while transferring technological knowledge is more likely to drive returnees to decide to become entrepreneurs than transferring business knowledge. Transferring a combination of technological and business knowledge is more contingent on perceived policy support and readjustment difficulties compared with transferring only one type of knowledge; and transferring only technological knowledge depends more on perceived policy support and cultural readjustment difficulties than transferring only business knowledge.

Do advancement levels of international knowledge transfer matter? Returnee brokers may also transfer knowledge with different levels of advancement. Some returnees may bring back internationally cutting-edge knowledge, whereas others may transfer knowledge that is new only to their home countries but is well established in their host countries (Zweig, Chung, \& Vanhonacker, 2006). Transferring more-advanced knowledge may have greater brokerage advantages but may also depend more on recontextualization in different institutional environments. To further understand the relationship between international knowledge transfer and returnee entrepreneurship, we performed an additional analysis to compare the transfer of knowledge with different levels of advancement.

We asked the respondents who reported bringing back advanced technological or business knowledge to China whether the technology or business model transferred is internationally cutting-edge or is new only to China. Then, we created two dummy variables, Transferring knowledge new only to the home country and Transferring cutting-edge knowledge, that we compared to the baseline category: "without international knowledge transfer".

The logistic regression results show that there is no significant difference between the effects of the two levels of knowledge transfer ( $\mathrm{p}=0.59$ of the one-degree-of-freedom test comparing means). The contingent effects of perceived policy support and readjustment difficulties on transferring cutting-edge knowledge and transferring knowledge that is new only to the home country have similar statistical significance. However, the effect sizes of both moderators are much stronger for transferring 
cutting-edge knowledge than that for transferring knowledge that is new only to the home country. The results indicate that transferring more-advanced knowledge does not largely influence the probability of becoming entrepreneurs. However, policy support and cross-cultural readjustment have stronger moderating effects on returnees who transfer more-advanced knowledge. More details of the results are discussed in Appendix 2.

\section{DISCUSSION}

International flows of commodities (e.g., exports) and capital (e.g., foreign direct investment) have been the focus of attention in the field of international business. However, in the intensified process of globalization, an emerging aspect of international flows, namely, international knowledge transfer through returnees, has gained increasing significance and has had important effects on international business and entrepreneurship. Building on the literature of knowledge brokerage and international entrepreneurship, we propose that returnees who transfer advanced knowledge serve as international knowledge brokers who enjoy information and control benefits in pursing entrepreneurial opportunities, thus bringing a new perspective to international entrepreneurship. Moreover, as international knowledge brokers face constraints and challenges when commercializing advanced knowledge gained overseas in their home countries, we explore the extent to which the relationship between international knowledge transfer and returnee entrepreneurship is contingent on the perceived benefits of policy support and cross-cultural readjustment difficulties.

Our findings show that returnees who transfer advanced technological knowledge and a combination of technological and business knowledge between host and home countries are more likely to become entrepreneurs. This result provides empirical evidence that returnee knowledge brokers enjoy the advantages of bridging cross-country knowledge gaps, which contribute to the identification and pursuit of international entrepreneurial opportunities. Previous research on international entrepreneurship has focused on the exploitation of opportunities (e.g., internationalization of small new ventures) (Keupp \& Gassmann, 2009), leaving the role of knowledge brokerage in opportunity identification, evaluation and the decision to pursue an opportunity largely underexplored (Ellis, 2011; Oviatt \& McDougall, 2005). There is a missing link between individual 
knowledge brokers across national boundaries and their entrepreneurial decisions. Our research contributes to an important but unrecognized source of international entrepreneurial opportunities by indicating that returnees, as a new form of international knowledge broker, not only transfer knowledge beyond national boundaries but also leverage brokerage advantages through entrepreneurship. This finding suggests that international entrepreneurship is a possible outcome of international knowledge brokerage. We also found boundary conditions for the relationship between international knowledge transfer and the decision to pursue an opportunity. Specifically, our findings show that perceived policy support for returnee entrepreneurship strengthens the positive relationship between international knowledge transfer and returnees' entrepreneurial decisions when the perceived benefits of policy support are relatively high. Returnees are more likely to capitalize on their knowledge advantages through entrepreneurial activities when the perceived readjustment difficulty is relatively low. However, there is a range of value regarding perceived policy support and readjustment difficulties that affects entrepreneurial decisions indirectly. A very low level of perceived policy support may be interpreted as a negligible factor in supporting entrepreneurship, whereas an excessive level of perceived cultural readjustment difficulties may imply a completely new environment, thus making cultural readjustment less relevant to making entrepreneurial decisions. Such boundary conditions may hinder returnees from pursuing entrepreneurial opportunities.

Our additional analysis shows that returnees transferring technological knowledge are more likely to decide to become entrepreneurs compared to returnees transferring business knowledge, while transferring a combination of both types of knowledge contributes to significantly higher probabilities of making entrepreneurial decisions compared with transferring only technological knowledge or only business knowledge. Furthermore, the boundary conditions for returnees' entrepreneurial decisions also differ depending on the type of knowledge being transferred. We find that brokering technological knowledge in deciding to become an entrepreneur depends more on perceived policy support and adjustment difficulties compared to transferring business knowledge. Compared with transferring only one type of knowledge, transferring a combination of technological knowledge and business knowledge is more contingent on perceived policy support and readjustment difficulties. It indicates that by complementing advanced technologies with business knowledge from the developed countries, 
returnee brokers are confronted with more uncertainty and thus require stronger support from the institutional environment.

We also seek to explore the variations in knowledge transfer with different levels of advancement. We find that transferring more-advanced knowledge (internationally cutting-edge knowledge compared to knowledge new only to the home country) does not lead to high probabilities of becoming an entrepreneur. This suggests that despite the greater information and control benefits provided by more-advanced overseas knowledge, cutting-edge knowledge generated in developed countries requires sufficient supporting conditions such as infrastructures, complementary assets, and skilled personnel, which are difficult to obtain in developing economies. The barriers due to cross-country institutional differences constrain returnee knowledge brokers’ willingness to realize brokerage advantages by starting their own businesses. The results also show that transferring more-advanced knowledge is more contingent on perceived policy support and readjustment difficulties, implying that this transfer requires greater recontextualization efforts to gain legitimacy and complementary resources compared to transferring less-advanced knowledge. Therefore, transferring more-advanced overseas knowledge may be a double-edged sword. Given the large potential of a home country market such as China, a new venture that transfers knowledge new only to the home country may be more profitable and easier to start than one that transfers cutting-edge knowledge.

International entrepreneurship studies have called attention to the differences between developing and developed countries in terms of institutional, cultural and political barriers (Kiss, Danis, \& Cavusgil, 2012). Although previous studies in international entrepreneurship have built a foundation on the relationship between the institutional environment and the exploitation of international opportunities, we know little about how institutional differences across countries affect entrepreneurs' evaluation of the uncertainty of exploiting an opportunity before making an actual move (Haynie et al., 2009). Contributing to this line of research, we explore the contingent factors that increase or reduce the perceived uncertainty associated with overcoming institutional barriers and transferring knowledge across borders through entrepreneurial activities. This study shows that transferring advanced knowledge is a double-edged sword that, on one hand, generates information and control benefits for 
opportunity discovery and, on the other hand, depends on perceptions about policy support and readjustment difficulties. Moreover, although the importance of the institutional environment for entrepreneurial activities has been documented, few studies have systemically examined the contextual conditions of returnee entrepreneurship (Acs, 2010). By studying a particular type of entrepreneurial activity, we show that returnee entrepreneurship based on international knowledge transfer is contingent on perceived policy support and returnees’ cross-cultural readjustment.

Our study advances the literature on brokerage and international entrepreneurship in several ways. First, this study contributes to the returnee entrepreneurship literature and extends our understanding of international entrepreneurship. Differing from previous research that has mainly examined the impacts of returnee entrepreneurs on organizational outcomes, our study investigates what drives returnee entrepreneurship. By considering returnees’ within-group heterogeneity, this study examines their variations in knowledge transfer and links international entrepreneurship to international knowledge brokerage, reflecting the increasing human mobility across national borders. Our findings highlight that cross-border knowledge brokerage is a key contributor to returnees' entrepreneurial decisions. In particular, while extant international entrepreneurship research has tended to focus on the exploitation of international opportunities (Ellis, 2011; Keupp \& Gassmann, 2009), this study extends the literature of international entrepreneurship (McDougall \& Oviatt, 2000) by highlighting international knowledge brokerage as a new source of entrepreneurship.

Furthermore, this study contributes to the brokerage literature by broadening the impact of international knowledge brokerage. While the literature on brokerage has proposed several advantages, including enhanced access to information and resources, which facilitates innovation and firm performance, this line of inquiry has seldom been extended to entrepreneurial decisions. Our study shows that international knowledge brokerage not only gives rise to organizational learning within MNEs (Reiche et al., 2009; Wang, 2015) but also generates benefits in identifying and deciding to pursue entrepreneurial opportunities. By linking the brokerage and the international entrepreneurship streams of literature, this study enriches our understanding of international knowledge brokerage through human mobility as an underlying mechanism that contributes to the decision to pursue entrepreneurial opportunities. 
Finally, this study sheds light on the complexity of international knowledge brokerage in the decision to pursue entrepreneurial opportunities. Prior studies have advocated the benefits of international knowledge brokerage (Liu et al., 2011; Wang, 2015) but have seldom conceptualized and empirically tested the extent to which potential entrepreneurs' perceptions of formal and informal institutional environments moderate the relationship between international knowledge transfer and entrepreneurial decisions. Our study fills this gap by showing that returnees’ perceived policy support from the home country and their cross-cultural readjustment difficulties may influence their assessment about the uncertainty of exploiting brokerage advantages through entrepreneurial activities. While returnee knowledge brokers enjoy information and control benefits that help them identify entrepreneurial opportunities, their perceptions of formal and informal business environments either facilitate or hinder their pursuit of entrepreneurial opportunities in their home country. Therefore, this study provides a more complete account of the interrelationships among international knowledge brokerage, perceived institutional conditions, and entrepreneurial decisions.

\section{Implications}

Our findings have important implications for policy makers and practitioners. First, institutional support is important for international knowledge brokers to transfer knowledge through entrepreneurial activities. Moreover, the transfer of more-advanced knowledge and a combination of technological and business knowledge is more dependent on policy support and cross-cultural readjustment. Therefore, for developing countries that aim to leapfrog from latecomer to leadership status by absorbing overseas advanced knowledge, governments must encourage international knowledge brokers to transfer cutting-edge knowledge or a richer combination of knowledge by providing sufficient infrastructures and institutional support. Second, our findings show that perceived difficulties in readjusting to local norms and cultures deter returnees' entrepreneurial decisions. Therefore, providing pre-return training to mitigate the strain associated with readjustment is also crucial for encouraging returnee entrepreneurship, especially potential entrepreneurs who transfer cutting-edge and diverse types of knowledge. Third, our findings provide implications for potential returnee entrepreneurs. The success of entrepreneurial activities relies not only on the transfer of 
advanced knowledge itself but also on the uncertainty associated with institutional support and self-readjustment. Hence, returnee entrepreneurs who transfer overseas advanced knowledge to their home countries must consider the complexity of different institutional contexts and their own readjustment capabilities. It is important to investigate the supportive conditions for knowledge transfer, such as infrastructures and government policies, and to be prepared for cross-cultural readjustment before making entrepreneurial decisions.

\section{Limitations and Future Research}

Our study has some limitations that present opportunities for future research. First, our study identifies and finds evidence that international knowledge brokerage is a source of international entrepreneurship. Because there are wide knowledge gaps among different countries, the findings are not limited to China; rather, they are generalizable to other developing countries. For example, returnee entrepreneurs have also played a significant role in the development of India, which is also a developing country that benefits from a rising trend of returning talent. However, our study does not examine returnees who move back to developed countries and other developing countries with formal and informal institutions that differ from those in China. Therefore, future studies might extend the sample to returnees in developed home countries or developing home countries with various degrees of home country government support and cross-cultural differences.

Second, because this study focuses on the effect of knowledge brokerage, which is proxied by international knowledge transfer, we have invested most of our efforts into controlling variances in overseas experience (e.g., overseas education, overseas work experience and overseas entrepreneurship experience). However, as previous studies have suggested, personal traits, values and motivations for going abroad also play important roles in entrepreneurial decisions. Future studies could provide a more comprehensive picture of returnee entrepreneurship by accessing more-extensive information about returnees' full career tracks and personal traits.

Third, the cross-sectional data used in the study limit causal inferences about the relationship between international knowledge transfer and returnees' entrepreneurial decisions. For example, international knowledge transfer is considered an antecedent of returnees' entrepreneurial decisions, 
but the opposite relationships cannot be fully dismissed, because the interplay between entrepreneurial decisions and knowledge transfer is dynamic in nature. Future research that uses longitudinal data spanning a longer period of time would be able to address the issue of possible reverse causality in the hypothesized relationships.

Fourth, the measurement of international knowledge transfer was measured by a dummy variable considering whether one of the two types of knowledge-technological knowledge and business knowledge-is being transferred. Although this study has further examined in additional analyses the variation among different types of knowledge transfer with different levels of advancement, future studies could use more-fine-grained measures that allow for more variance, such as scales. Moreover, there are many other aspects of institutional support, such as facilitating networking and clustering and cultivating preferential normative institutions for entrepreneurship. Future studies could examine various types of institutional support and could differentiate their effects on returnee entrepreneurship.

Finally, because existing studies on returnees have mainly focused on the effect of returnee entrepreneurs on venture success, our study attempts to understand a neglected question: why do some returnees become entrepreneurs while others do not? However, how international knowledge transfer affects venture success is also an interesting and important question, though it is beyond the scope of the current study. Therefore, future studies should systematically examine the factors that contribute to the performance of different types of new ventures founded by returnee entrepreneurs.

\section{CONCLUSION}

Our research focuses on an emerging phenomenon-returnee entrepreneurship. Using survey data, we investigate the relationship between returnee brokers' international knowledge transfer and their entrepreneurial decisions as well as the contingent effects of perceived policy support for returnee entrepreneurship and returnees' cross-cultural readjustment difficulties. The findings show that returnees who transfer overseas knowledge have brokerage advantages and are more likely to make entrepreneurial decisions. The results further reveal that the appropriation of international brokerage advantages through entrepreneurship depends on the potential returnee entrepreneurs' perceptions of their formal and informal institutional environments. Specifically, the perceived benefits from policy 
support from the home country strengthens the relationship between international knowledge transfer and returnees' entrepreneurial decisions, whereas perceived difficulties associated with readjustment to local norms and culture weaken the relationship. Moreover, additional analyses show that transferring technological knowledge has a stronger effect on returnees' entrepreneurial decisions but is more dependent on the perceived policy support and readjustment difficulties compared to transferring business knowledge. It is also shown that transferring a combination of technological and business knowledge contributes to higher probabilities of becoming an entrepreneur than transferring only one type of knowledge. Meanwhile, transferring internationally cutting-edge knowledge or a combination of technological and business knowledge through new firm formation is more contingent on the perceived policy support and cross-cultural readjustment than transferring less-advanced knowledge or only one type of knowledge. By identifying returnees as international knowledge brokers and linking their knowledge brokerage advantages with international entrepreneurship, this study provides new insights into the research on international entrepreneurship.

\section{ACKNOWLEDGEMENTS}

We are grateful to the Editor Professor Paula Caligiuri and three anonymous reviewers for their insightful comments. This paper was partially funded by research grants from the National Science Foundation of China (\#71472010; \# 71172020; \#71525004 and \#71502180). 


\section{REFERENCES}

Acs, Z. J. 2010. High-impact entrepreneurship. In Z. J. Acs, \& D. B. Audretsch (Ed.), Handbook of Entrepreneurship Research: 165-182. New York: Springer.

Agarwal, R., Audretsch, D., \& Sarkar, M. 2007. The process of creative construction: Knowledge spillovers, entrepreneurship, and economic growth. Strategic Entrepreneurship Journal, 1(3-4): 263-286.

Agarwal, R., Echambadi, R., Franco, A. M., \& Sarkar, M. B. 2004. Knowledge transfer through inheritance: Spinout generation, development, and survival. Academy of Management Journal, 47(4): 501-522.

Agrawal, A., Kapur, D., McHale, J., \& Oettl, A. 2011. Brain drain or brain bank? The impact of skilled emigration on poor-country innovation. Journal of Urban Economics, 69(1): 43-55.

Bae, J., Wezel, F. C., \& Koo, J. 2011. Cross-cutting ties, organizational density, and new firm formation in the US Biotech Industry, 1994-98. Academy of Management Journal, 54(2): 295-311.

Baker, T., Gedajlovic, E., \& Lubatkin, M. 2005. A framework for comparing entrepreneurship processes across nations. Journal of International Business Studies, 36(5): 492-504.

Barner-Rasmussen, W., Ehrnrooth, M., Koveshnikov, A., \& Mäkelä, K. 2014. Cultural and language skills as resources for boundary spanning within the MNC. Journal of International Business Studies, 45(7): 886-905.

Batjargal, B., Hitt, M. A., Tsui, A. S., Arregle, J.-L., Webb, J. W., \& Miller, T. L. 2013. Institutional polycentrism, entrepreneurs' social networks, and new venture growth. Academy of Management Journal, 56(4): 1024-1049.

Black, J. S., Gregersen, H. B., \& Mendenhall, M. E. 1992. Toward a theoretical framework of repatriation adjustment. Journal of International Business Studies, 23(4): 737-760.

Brannen, M. Y. 2004. When Mickey loses face: Recontextualization, semantic fit, and the semiotics of foreignness. Academy of Management Review, 29(4): 593-616.

Bruton, G. D., Ahlstrom, D., \& Li, H. L. 2010. Institutional theory and entrepreneurship: Where are we now and where do we need to move in the future? Entrepreneurship Theory and Practice, 34(3): 421-440.

Burt, R. S. 1992. Structural Holes: The Social Structure of Competition. Cambridge: Harvard University Press.

Burt, R. S. 2004. Structural holes and good ideas. American Journal of Sociology, 110(2): 349-399.

Caligiuri, P. 2014. Many moving parts: Factors influencing the effectiveness of HRM practices designed to improve knowledge transfer within MNCs. Journal of International Business Studies, 45(1): 63-72.

Chang, S.-J., van Witteloostuijn, A., \& Eden, L. 2010. From the editors: Common method variance in international business research. Journal of International Business Studies, 41(2): 178-184.

Choi, Y. R., \& Shepherd, D. A. 2004. Entrepreneurs' decisions to exploit opportunities. Journal of Management, 30(3): 377-395.

Creswell, J. W. 2013. Research design: Qualitative, quantitative, and mixed methods approaches. Thousand Oaks, CA: Sage publications.

Davidsson, P., \& Honig, B. 2003. The role of social and human capital among nascent entrepreneurs. Journal of Business Venturing, 18(3): 301-331.

Drucker, P. 1985. Innovation and entrepreneurship. New York: Harper \& Row.

Dyer, J. H., Gregersen, H. B., \& Christensen, C. 2008. Entrepreneur behaviors, opportunity recognition, and the origins of innovative ventures. Strategic Entrepreneurship Journal, 2(4): 317-338.

Eckhardt, J. T., \& Shane, S. A. 2003. Opportunities and entrepreneurship. Journal of Management, 29(3): 333-349.

Ellis, P. D. 2010. Effect sizes and the interpretation of research results in international business. Journal of International Business Studies, 41(9): 1581-1588.

Ellis, P. D. 2011. Social ties and international entrepreneurship: Opportunities and constraints affecting firm internationalization. Journal of International Business Studies, 42(1): 99-127. 
Falk, R. 2007. Measuring the effects of public support schemes on firms' innovation activities - Survey evidence from Austria. Research Policy, 36(5): 665-679.

Filatotchev, I., Liu, X. H., Buck, T., \& Wright, M. 2009. The export orientation and export performance of high-technology SMEs in emerging markets: The effects of knowledge transfer by returnee entrepreneurs. Journal of International Business Studies, 40(6): 1005-1021.

Furuya, N., Stevens, M. J., Bird, A., Oddou, G., \& Mendenhall, M. 2009. Managing the learning and transfer of global management competence: Antecedents and outcomes of Japanese repatriation effectiveness. Journal of International Business Studies, 40(2): 200-215.

Gabrielsson, J., \& Politis, D. 2011. Career motives and entrepreneurial decision-making: examining preferences for causal and effectual logics in the early stage of new ventures. Small Business Economics, 36(3): 281-298.

Gruber, M., MacMillan, I. C., \& Thompson, J. D. 2012. From minds to markets: How human capital endowments shape market opportunity identification of technology start-ups. Journal of Management, 38(5): 1421-1449.

Guler, I., \& Guillen, M. F. 2010. Home country networks and foreign expansion: Evidence from the venture capital industry. Academy of Management Journal, 53(2): 390-410.

Haynie, J. M., Shepherd, D. A., \& McMullen, J. S. 2009. An Opportunity for Me? The Role of Resources in Opportunity Evaluation Decisions. Journal of Management Studies, 46(3): 337-361.

Hinkin, T. R. 1998. A brief tutorial on the development of measures for use in survey questionnaires. Organizational Research Methods, 1(1): 104-121.

Hoskisson, R. E., Eden, L., Lau, C. M., \& Wright, M. 2000. Strategy in emerging economies. Academy of Management Journal, 43(3): 249-267.

Huber, F. 2013. Knowledge-sourcing of R\&D workers in different job positions: Contextualising external personal knowledge networks. Research Policy, 42(1): 167-179.

Kenney, M., Breznitz, D., \& Murphree, M. 2012. Coming back home after the sun rises: Returnee entrepreneurs and growth of high tech industries. Research Policy, 42(2): 391-407.

Keupp, M. M., \& Gassmann, O. 2009. The past and the future of international entrepreneurship: A review and suggestions for developing the field. Journal of Management, 35(3): 600-633.

Kiss, A. N., Danis, W. M., \& Cavusgil, S. T. 2012. International entrepreneurship research in emerging economies: A critical review and research agenda. Journal of Business Venturing, 27(2): 266-290.

Kraimer, M. L., \& Wayne, S. J. 2004. An examination of perceived organizational support as a multidimensional construct in the context of an expatriate assignment. Journal of Management, 30(2): 209-237.

Krueger, N. F., Jr. 2000. The cognitive infrastructure of opportunity emergence. Entrepreneurship Theory and Practice, 24(3).

Lazarova, M., \& Caligiuri, P. 2001. Retaining repatriates: The role of organizational support practices. Journal of World Business, 36(4): 389-401.

Lazarova, M. B., \& Cerdin, J. L. 2007. Revisiting repatriation concerns: Organizational support versus career and contextual influences. Journal of International Business Studies, 38(3): 404-429.

Levin, D. Z., \& Barnard, H. 2013. Connections to distant knowledge: Interpersonal ties between moreand less-developed countries. Journal of International Business Studies, 44(7): 676-698.

Li, H., Zhang, Y., Li, Y., Zhou, L.-A., \& Zhang, W. 2012. Returnees versus locals: Who perform better in China's technology entrepreneurship? Strategic Entrepreneurship Journal, 6(3): 257-272.

Li, H. Y., \& Atuahene-Gima, K. 2001. Product innovation strategy and the performance of new technology ventures in China. Academy of Management Journal, 44(6): 1123-1134.

Lim, D. S. K., Morse, E. A., Mitchell, R. K., \& Seawright, K. K. 2010. Institutional environment and entrepreneurial cognitions: A comparative business systems perspective. Entrepreneurship Theory and Practice, 34(3): 491-516.

Liu, X. H., Lu, J. Y., Filatotchev, I., Buck, T., \& Wright, M. 2010. Returnee entrepreneurs, knowledge spillovers and innovation in high-tech firms in emerging economies. Journal of International Business Studies, 41(7): 1183-1197.

Long, C. S., \& Ismail, W. K. W. 2011. An analysis of the relationship between HR professionals' 
competencies and firms' performance in Malaysia. International Journal of Human Resource Management, 22(5): 1054-1068.

Luo, Y. D. 2001. Toward a cooperative view of MNC-host government relations: Building blocks and performance implications. Journal of International Business Studies, 32(3): 401-419.

McDougall, P. P., \& Oviatt, B. M. 2000. International entrepreneurship: The intersection of two research paths. Academy of Management Journal, 43(5): 902-906.

McMullen, J. S., \& Shepherd, D. A. 2006. Entrepreneurial action and the role of uncertainty in the theory of the entrepreneur. Academy of Management Review, 31(1): 132-152.

Minniti, M. 2004. Entrepreneurial alertness and asymmetric information in a spin-glass model. Journal of Business Venturing, 19(5): 637-658.

Mitchell, M. N. 2012. Interpreting and Visualizing Regression Models Using Stata. College Station: Stata Press.

Oddou, G., Osland, J. S., \& Blakeney, R. N. 2009. Repatriating knowledge: variables influencing the "transfer" process. Journal of International Business Studies, 40(2): 181-199.

Oettl, A., \& Agrawal, A. 2008. International labor mobility and knowledge flow externalities. Journal of International Business Studies, 39(8): 1242-1260.

Oviatt, B. M., \& McDougall, P. P. 2005. The internationalization of entrepreneurship. Journal of International Business Studies, 36(1): 2-8.

Podsakoff, P. M., MacKenzie, S. B., Lee, J.-Y., \& Podsakoff, N. P. 2003. Common method biases in behavioral research: A critical review of the literature and recommended remedies. Journal of Applied Psychology, 88(5): 879.

Podsakoff, P. M., \& Organ, D. W. 1986. Self-reports in organizational research: Problems and prospects. Journal of Management, 12(4): 531-544.

Qin, F., \& Estrin, S. 2015. Does Social Influence Span Time and Space? Evidence from Indian Returnee Entrepreneurs. Strategic Entrepreneurship Journal, 9(3): 226-242.

Reiche, B. S., Harzing, A. W., \& Kraimer, M. L. 2009. The role of international assignees' social capital in creating inter-unit intellectual capital: A cross-level model. Journal of International Business Studies, 40(3): 509-526.

Riddle, L., \& Brinkerhoff, J. 2011. Diaspora entrepreneurs as institutional change agents: The case of Thamel.com. International Business Review, 20(6): 670-680.

Rowley, T., Behrens, D., \& Krackhardt, D. 2000. Redundant governance structures: An analysis of structural and relational embeddedness in the steel and semiconductor industries. Strategic Management Journal, 21(3): 369-386.

Sapienza, H. J., \& Gupta, A. K. 1994. Impact of agency risks and task uncertainty on venture capitalist-CEO interaction. Academy of Management Journal, 37(6): 1618-1632.

Saxenian, A. 2005. From brain drain to brain circulation: Transnational communities and regional upgrading in India and China. Studies in Comparative International Development, 40(2): 35-61.

Shane, S., \& Venkataraman, S. 2000. The promise of entrepreneurship as a field of research. Academy of Management Review, 25(1): 217-226.

Shepherd, D. A., Williams, T. A., \& Patzelt, H. 2015. Thinking about entrepreneurial decision making: Review and research agenda. Journal of Management, 41(1): 11-46.

Simon, M., Houghton, S. M., \& Aquino, K. 2000. Cognitive biases, risk perception, and venture formation: How individuals decide to start companies. Journal of business venturing, 15(2): 113-134.

Spencer, J. W. 2003. Global gatekeeping, representation, and network structure: a longitudinal analysis of regional and global knowledge-diffusion networks. Journal of International Business Studies, 34(5): 428-442.

Stam, W., Arzlanian, S., \& Elfring, T. 2014. Social capital of entrepreneurs and small firm performance: A meta-analysis of contextual and methodological moderators. Journal of Business Venturing, 29(1): 152-173.

Stenholm, P., Acs, Z. J., \& Wuebker, R. 2013. Exploring country-level institutional arrangements on the rate and type of entrepreneurial activity. Journal of Business Venturing, 28(1): 176-193.

Vasudeva, G., Zaheer, A., \& Hernandez, E. 2013. The embeddedness of networks: Institutions, structural holes, and innovativeness in the fuel cell industry. Organization Science, 24(3): 


\section{5-663.}

Wang, D. 2015. Activating brokerage: Inter-organizational knowledge transfer through skilled return migration. Administrative Science Quarterly, 60(1): 133-176.

Williams, R. 2012. Using the margins command to estimate and interpret adjusted predictions and marginal effects. The Stata Journal, 12(2): 308-331.

Wright, M., Liu, X. H., Buck, T., \& Filatotchev, I. 2008. Returnee entrepreneurs, science park location choice and performance: An analysis of high-technology SMEs in China. Entrepreneurship Theory and Practice, 32(1): 131-155.

Xiao, Z. X., \& Tsui, A. S. 2007. When brokers may not work: The cultural contingency of social capital in Chinese high-tech firms. Administrative Science Quarterly, 52(1): 1-31.

Zelner, B. A. 2009. Using simulation to interpret results from logit, probit, and other nonlinear models. Strategic Management Journal, 30(12): 1335-1348.

Zweig, D., Chung, S. F., \& Vanhonacker, W. 2006. Rewards of technology: Explaining China’s reverse migration. Journal of International Migration and Integration, 7(4): 449-471.

\footnotetext{
1 The definition of returnees given here differs from that of organizational repatriates, as the former includes individuals who left their home countries for the purpose of higher education and training in foreign countries and returned to their home countries after obtaining a higher degree/training or work experience. Organizational repatriates were employees who were sent overseas by MNEs and returned to their home countries and continue to work in the MNEs after their international assignments (Lazarova \& Caligiuri, 2001).

${ }^{2}$ Home countries have issued specific policies to attract and support returnee entrepreneurs to facilitate the innovation and entrepreneurship led by returnees with advanced knowledge, which accelerates the growth of the developing home countries. Most of the supportive policies target returnees with certain requirements, such as overseas degrees and work experience. Overall, policy support targets highly skilled returnees and aims at promoting innovation and entrepreneurship in the home country.

According to the National Bureau of Statistics of China, in 2013, approximately 354,000 returnees came back to China from overseas.

Data source: National Bureau of Statistics of China. http://data.stats.gov.cn/workspace/index?m=hgnd

4 The responses on the scales of Policy support for returnee entrepreneurship, Readjustment difficulties of returnees and Policy support for returnee family are as follows: 1 - Strongly disagree; 2 - Disagree; 3 Somewhat disagree; 4 - Neutral; 5 - Somewhat agree; 6 - Agree; 7 - Strongly agree.

5 The seven strategic emerging industries include new generations of the information technology, biology, high-end equipment manufacturing, new energy, new material, new energy auto, energy-saving and environmental protection industries.

${ }^{6}$ China's State Council issued the “12th Five-Year Plan Outline” and laid out seven strategic emerging industries.

7 All appendices are included in the "Online Supporting Information”.

${ }^{8}$ We coded the three levels of international knowledge transfer into two dummies, following the scheme in http://www.ats.ucla.edu/stat/stata/webbooks/reg/chapter5/statareg5.htm.
} 
Table 1. Construct measurement of moderators and factor analysis

\begin{tabular}{|c|c|c|c|}
\hline & $\begin{array}{l}\text { EFA } \\
\text { Rotated factor } \\
\text { loadings }\end{array}$ & $\begin{array}{l}\text { CFA } \\
\text { One-factor } \\
\text { model }\end{array}$ & $\begin{array}{l}\text { CFA } \\
\text { Two-factor } \\
\text { model }\end{array}$ \\
\hline \multicolumn{4}{|l|}{$\begin{array}{l}\text { Perceived policy support for returnee entrepreneurship } \\
\text { (Cronbach's alpha }=\mathbf{0 . 8 7} \text { ) }\end{array}$} \\
\hline $\begin{array}{l}\text { Government policies support technology development led by } \\
\text { returnees. }\end{array}$ & 0.78 & 0.76 & 0.76 \\
\hline $\begin{array}{l}\text { Government policies provide a wide range of funding for returnee } \\
\text { enterprises. }\end{array}$ & 0.89 & 0.88 & 0.88 \\
\hline $\begin{array}{l}\text { Government policies support returnee entrepreneurs' loan } \\
\text { applications. }\end{array}$ & 0.90 & 0.90 & 0.90 \\
\hline $\begin{array}{l}\text { Government policies place less restrictions on importing } \\
\text { technological apparatuses that returnee enterprises need for R\&D. }\end{array}$ & 0.82 & 0.74 & 0.73 \\
\hline \multicolumn{4}{|l|}{$\begin{array}{l}\text { Perceived readjustment difficulties of returnees } \\
(\text { Cronbach's alpha }=\mathbf{0 . 7 5})\end{array}$} \\
\hline Returnees' management orientations do not work in China. & 0.78 & 0.14 & 0.69 \\
\hline $\begin{array}{l}\text { Returnees' behaviors do not match the way of conducting business } \\
\text { in China. }\end{array}$ & 0.77 & 0.11 & 0.71 \\
\hline Returnees do not understand the rules of the game in China. & 0.80 & 0.17 & 0.58 \\
\hline $\begin{array}{l}\text { Returnees' beliefs from Western culture conflict with Chinese } \\
\text { culture. }\end{array}$ & 0.71 & 0.32 & 0.69 \\
\hline \multicolumn{4}{|l|}{ Fit statistics } \\
\hline Chi square $(\mathrm{d} f)$ & & $257.00(20)^{* * *}$ & $36.13(19)^{*}$ \\
\hline CFI & & 0.72 & 0.98 \\
\hline NFI & & 0.70 & 0.96 \\
\hline RMSEA & & 0.17 & 0.05 \\
\hline AIC & & 305.00 & 86.13 \\
\hline$\Delta \chi^{2}(\Delta \mathrm{d} f)$ & & & $220.87(1)^{* * *}$ \\
\hline
\end{tabular}

Note: ${ }^{*} \mathrm{p}<0.05,{ }^{* *} \mathrm{p}<0.01, * * * \mathrm{p}<0.001$ 
Table 2. Summary statistics and correlation analysis

\begin{tabular}{|c|c|c|c|c|c|c|c|c|c|c|c|c|c|c|c|c|c|c|c|}
\hline & Mean & S.D. & Min & Max & 1 & 2 & 3 & 4 & 5 & 6 & 7 & 8 & 9 & 10 & 11 & 12 & 13 & 14 & 15 \\
\hline 1.Returnees' entrepreneurship decisions & 0.6 & 0.49 & 0 & 1 & & & & & & & & & & & & & & & \\
\hline 2.International knowledge transfer & 0.74 & 0.44 & 0 & 1 & 0.4 & & & & & & & & & & & & & & \\
\hline 3.Perceived policy support for returnee entrepreneurship & -0.01 & 0.99 & -3.25 & 1 & -0.01 & 0.06 & & & & & & & & & & & & & \\
\hline 4.Perceived readjustment difficulties of returnees & 0.01 & 1 & -2.93 & 1.84 & -0.04 & 0.08 & 0.13 & & & & & & & & & & & & \\
\hline 5.Gender & 0.81 & 0.4 & 0 & 1 & 0.22 & 0.35 & -0.12 & 0.19 & & & & & & & & & & & \\
\hline 6.Age at return & 35.78 & 8.22 & 22 & 59 & 0.35 & 0.24 & -0.04 & 0.07 & 0.26 & & & & & & & & & & \\
\hline 7.Overseas duration & 9.72 & 6.14 & 1 & 26 & 0.34 & 0.2 & -0.04 & 0.1 & 0.24 & 0.8 & & & & & & & & & \\
\hline 8.Number of host countries & 2.05 & 1.91 & 1 & 10 & 0.07 & 0.12 & -0.03 & 0.01 & -0.01 & 0.15 & 0.22 & & & & & & & & \\
\hline 9.Entrepreneurial attributes & -0.01 & 0.49 & -1.87 & 1.09 & 0.04 & 0.2 & 0.38 & 0.21 & 0.07 & -0.06 & 0.01 & 0.01 & & & & & & & \\
\hline 10.Overseas doctoral degree & 0.56 & 0.5 & 0 & 1 & 0.23 & 0.29 & 0.07 & 0 & 0.23 & 0.28 & 0.22 & 0.07 & -0.16 & & & & & & \\
\hline 11.Overseas work experience & 4.67 & 4.67 & 0 & 22 & 0.36 & 0.17 & -0.1 & 0.01 & 0.21 & 0.77 & 0.9 & 0.24 & 0.01 & 0.08 & & & & & \\
\hline 12.Overseas entrepreneurship experience & 0.29 & 0.45 & 0 & 1 & 0.39 & 0.21 & -0.15 & -0.02 & 0.21 & 0.4 & 0.48 & 0.15 & -0.03 & 0.07 & 0.51 & & & & \\
\hline 13.Major in sciences or engineering & 0.68 & 0.47 & 0 & 1 & 0.3 & 0.25 & -0.03 & 0.08 & 0.32 & 0.26 & 0.27 & -0.05 & -0.07 & 0.49 & 0.22 & 0.09 & & & \\
\hline 14.Developed host country & 0.78 & 0.41 & 0 & 1 & 0.17 & -0.05 & 0.08 & -0.06 & -0.06 & 0.04 & 0.03 & 0.08 & -0.01 & -0.1 & 0.08 & 0.07 & -0.14 & & \\
\hline 15.Policy support for returnee family & -0.01 & 0.98 & -1.26 & 3.13 & 0.07 & -0.04 & -0.21 & -0.27 & 0 & -0.04 & -0.05 & -0.09 & -0.14 & 0.09 & 0 & -0.01 & 0.11 & -0.01 & \\
\hline 16.Strategic emerging industry & 0.62 & 0.49 & 0 & 1 & 0.5 & 0.32 & 0 & 0.13 & 0.36 & 0.11 & 0.17 & -0.01 & 0.04 & 0.23 & 0.14 & 0.16 & 0.49 & 0.05 & 0.03 \\
\hline
\end{tabular}

Note: Correlations with an absolute value equal to or larger than 0.13 are significant at or above $5 \%$. 
Table 3. Logistic regressions of international knowledge transfer on returnees' entrepreneurial decisions

\begin{tabular}{|c|c|c|c|c|c|}
\hline & Model 1 & Model 2 & Model 3 & Model 4 & Model 5 \\
\hline \multirow[t]{2}{*}{ Gender } & -0.7 & -1.04 & -1.17 & -0.96 & -1.24 \\
\hline & $(0.55)$ & $(0.59)$ & $(0.62)$ & $(0.61)$ & $(0.65)$ \\
\hline \multirow[t]{2}{*}{ Age at return (log) } & $3.20 *$ & $2.52+$ & 2.33 & $3.47 *$ & 3.18 \\
\hline & $(1.47)$ & $(1.52)$ & $(1.52)$ & $(1.65)$ & $(1.64)$ \\
\hline \multirow[t]{2}{*}{ Overseas duration (log) } & -1.06 & -0.77 & -0.71 & -0.82 & -0.8 \\
\hline & $(0.62)$ & $(0.66)$ & $(0.67)$ & $(0.69)$ & $(0.72)$ \\
\hline \multirow[t]{2}{*}{ Number of host countries } & 0.04 & -0.03 & -0.03 & -0.01 & -0.01 \\
\hline & $(0.12)$ & $(0.12)$ & $(0.12)$ & $(0.12)$ & $(0.12)$ \\
\hline \multirow[t]{2}{*}{ Entrepreneurial attributes } & 0.92 & 0.5 & 0.48 & 0.55 & 0.59 \\
\hline & $(0.47)$ & $(0.50)$ & $(0.56)$ & $(0.51)$ & $(0.58)$ \\
\hline \multirow[t]{2}{*}{ Overseas doctoral degree } & 0.71 & 0.46 & 0.39 & 0.36 & 0.34 \\
\hline & $(0.51)$ & $(0.52)$ & $(0.54)$ & $(0.53)$ & $(0.55)$ \\
\hline \multirow[t]{2}{*}{ Overseas work experience (log) } & $1.12 *$ & 1.04 & 0.98 & 1.10 & 1.08 \\
\hline & $(0.56)$ & $(0.57)$ & $(0.58)$ & $(0.59)$ & $(0.60)$ \\
\hline \multirow[t]{2}{*}{ Overseas entrepreneurship experience } & $1.95^{* *}$ & $1.82 * *$ & $1.95^{* *}$ & $1.77 * *$ & $1.86^{* *}$ \\
\hline & $(0.59)$ & $(0.61)$ & $(0.63)$ & $(0.62)$ & $(0.64)$ \\
\hline \multirow[t]{2}{*}{ Major in sciences or engineering } & 0.06 & 0.06 & 0.2 & 0.18 & 0.38 \\
\hline & $(0.53)$ & $(0.55)$ & $(0.57)$ & $(0.56)$ & $(0.58)$ \\
\hline \multirow[t]{2}{*}{ Developed host country } & $1.09 *$ & $1.24 *$ & $1.24 *$ & $1.09 *$ & $1.13^{*}$ \\
\hline & $(0.48)$ & $(0.50)$ & $(0.50)$ & $(0.52)$ & $(0.52)$ \\
\hline \multirow[t]{2}{*}{ Policy support for returnee family } & 0.26 & 0.26 & 0.26 & 0.23 & 0.25 \\
\hline & $(0.20)$ & $(0.20)$ & $(0.21)$ & $(0.22)$ & $(0.23)$ \\
\hline \multirow[t]{2}{*}{ Strategic emerging industry } & $2.86 * * *$ & $2.71 * * *$ & $2.70 * * *$ & $2.87 * * *$ & $2.84 * * *$ \\
\hline & $(0.52)$ & $(0.53)$ & $(0.54)$ & $(0.56)$ & $(0.57)$ \\
\hline \multirow[t]{2}{*}{ International knowledge transfer } & & $0.63^{* *}$ & $0.65 * *$ & $0.60 * *$ & $0.65 * *$ \\
\hline & & $(0.22)$ & $(0.22)$ & $(0.22)$ & $(0.23)$ \\
\hline \multirow[t]{2}{*}{ Perceived policy support for returnee entrepreneurship } & & & 1.00E-04 & & -0.09 \\
\hline & & & $(0.26)$ & & $(0.28)$ \\
\hline \multirow[t]{2}{*}{$\begin{array}{l}\text { International knowledge transfer } \\
\text { x Perceived policy support for returnee entrepreneurship }\end{array}$} & & & 0.3 & & 0.41 \\
\hline & & & $(0.21)$ & & $(0.24)$ \\
\hline \multirow[t]{2}{*}{ Perceived readjustment difficulties of returnees } & & & & -0.38 & -0.25 \\
\hline & & & & $(0.25)$ & $(0.26)$ \\
\hline \multirow[t]{2}{*}{$\begin{array}{l}\text { International knowledge transfer } \\
\text { x Perceived readjustment difficulties of returnees }\end{array}$} & & & & -0.42 & $-0.60 *$ \\
\hline & & & & $(0.22)$ & $(0.27)$ \\
\hline Home country location dummies & YES & YES & YES & YES & YES \\
\hline \multirow[t]{2}{*}{ Constant } & $-13.45^{* *}$ & $-10.98 *$ & $-10.26^{*}$ & $-14.38 * *$ & $-13.25 *$ \\
\hline & (4.91) & (5.07) & $(5.07)$ & (5.56) & (5.56) \\
\hline Chi2 & 120.59 & 129.32 & 131.76 & 135.32 & 139.01 \\
\hline Log likelihood & -85.42 & -81.05 & -79.83 & -78.05 & -76.21 \\
\hline $\mathrm{N}$ & 217 & 217 & 217 & 217 & 217 \\
\hline
\end{tabular}


Figure 1. Graphic presentations of the interaction between International knowledge transfer and Perceived policy support for returnee entrepreneurship.

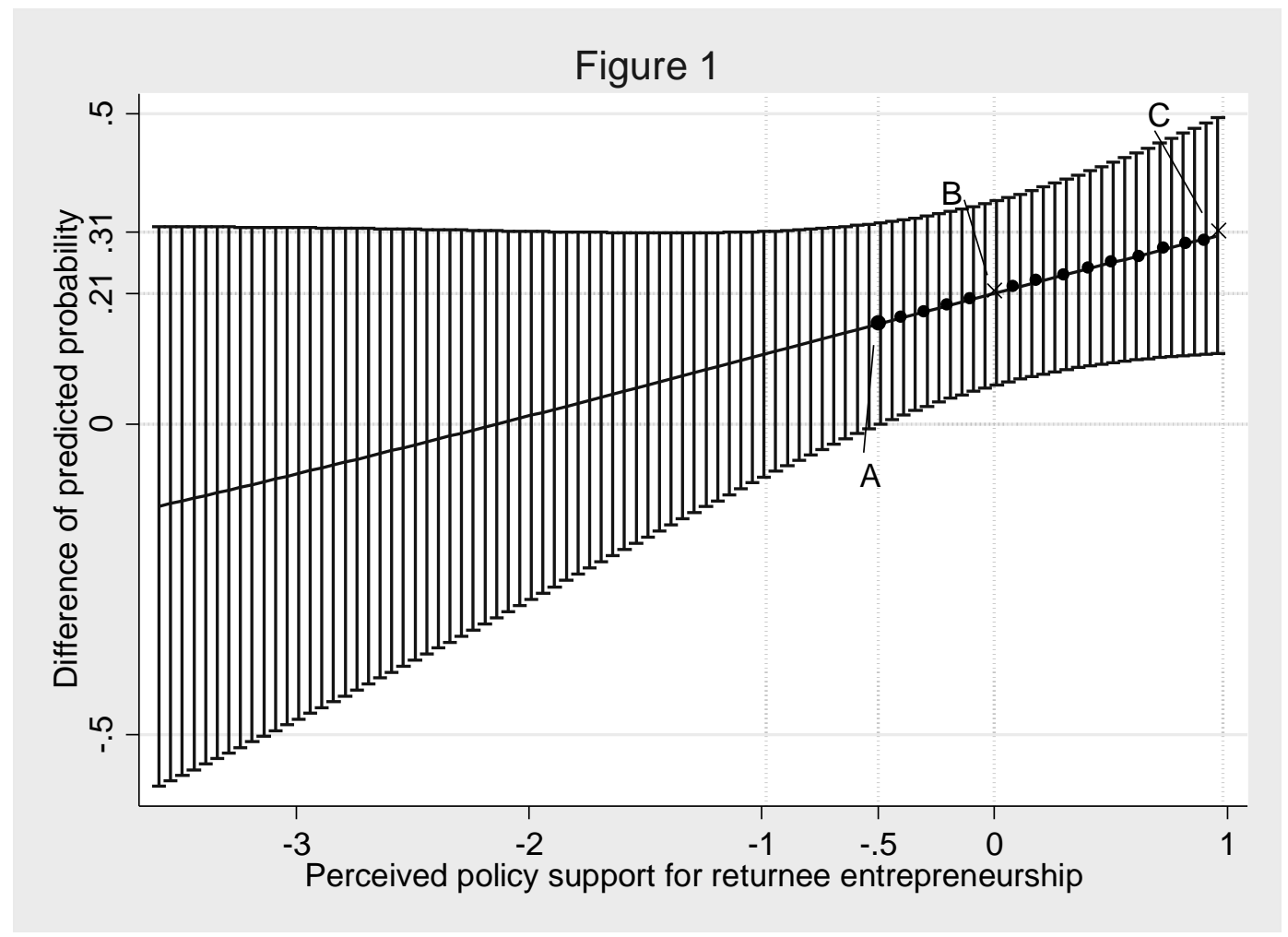

Notes:

- The y-axis in Figure 1 represents the difference in the predicted probabilities of entrepreneurial decisions between returnees with international knowledge transfer and returnees without international knowledge transfer against Perceived policy support for returnee entrepreneurship (x-axis). All other explanatory variables are held at mean values in Model 3 of Table 3 . The bars surrounding the line indicate the $95 \%$ confidence interval. The solid circles on the line indicate the range at which the difference is statistically significant at the 0.05 level. The range above the factor score of -0.5 of Perceived policy support for returnee entrepreneurship indicates that the interaction is significant at the 0.05 level for over $76 \%$ of the observations. 
Figure 2. Graphic presentations of the interaction between International knowledge transfer and Readjustment difficulties of returnees.

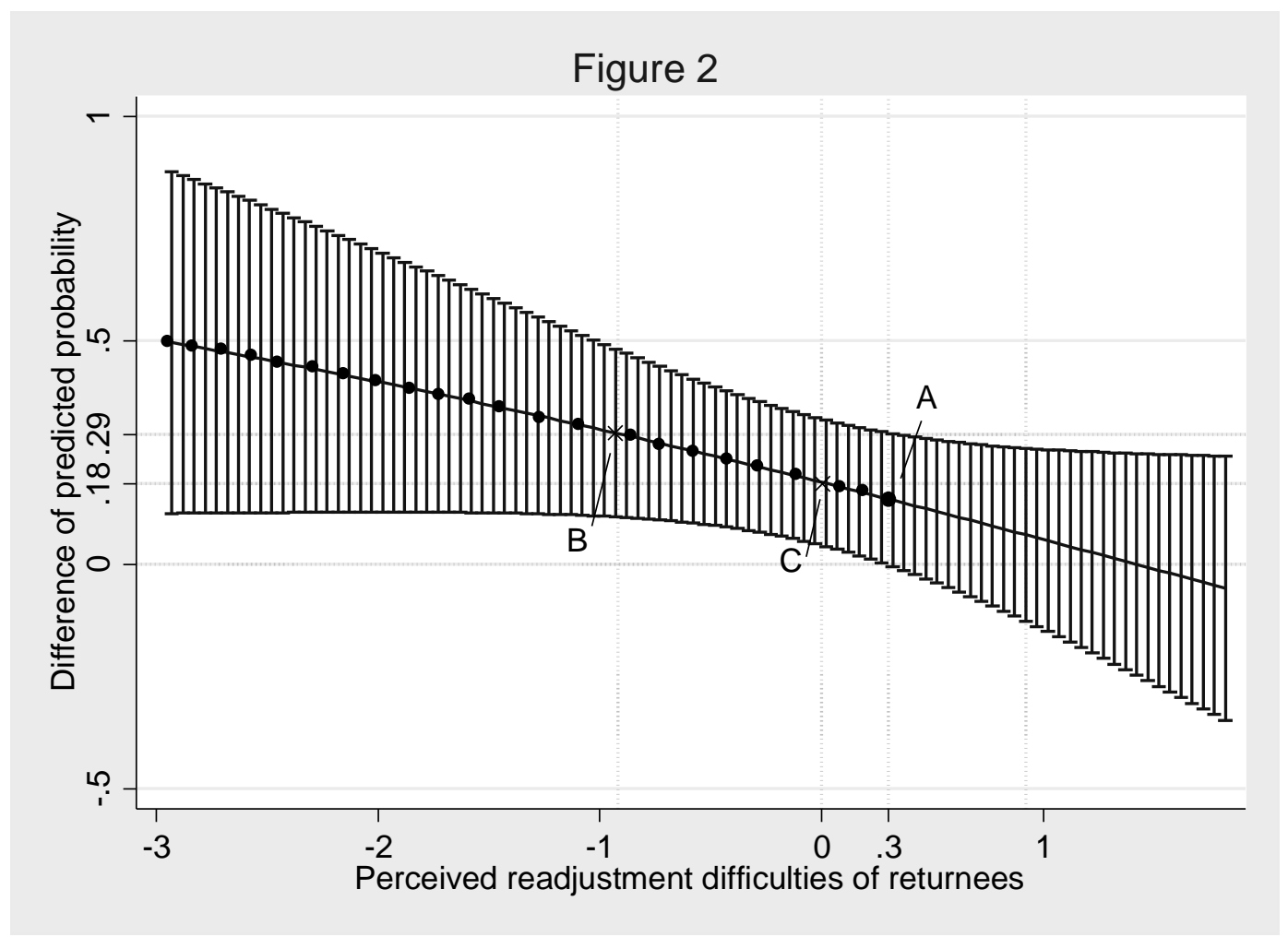

\section{Notes:}

- The y-axis in Figure 2 represents the difference in the predicted probabilities of entrepreneurial decisions between returnees with international knowledge transfer and returnees without international knowledge transfer against Perceived readjustment difficulties of returnees (x-axis). All other explanatory variables are held at the mean values in Model 4 of Table 3. The bars surrounding the line indicate the 95\% confidence interval. The solid circles on the line indicate the range at which the difference is statistically significant at the 0.05 level. The range below the factor score of 0.3 of Perceived readjustment difficulties of returnees indicates that the interaction is significant at the 0.05 level for over $60 \%$ of the observations. 
Table 4. Qualitative evidence on how international knowledge transfer affects returnees' entrepreneurial decisions

\begin{tabular}{|c|c|c|c|}
\hline $\begin{array}{l}\text { Entrepreneur } \\
\text { interviewee }\end{array}$ & $\begin{array}{l}\text { International } \\
\text { knowledge } \\
\text { transfer }\end{array}$ & Information benefits about international knowledge gaps & Control benefits over filling the international knowledge gaps \\
\hline A & $\begin{array}{l}\text { Bringing back } \\
\text { technology in } \\
\text { gene chips. }\end{array}$ & $\begin{array}{l}\text { "Based on my experience and expertise, the gene chip } \\
\text { technology development of China usually lags } 7 \text { months to two } \\
\text { years compared to the U.S. Witnessing the gene chip technology } \\
\text { growing from the first generation to the second generation in the } \\
\text { U.S., I know that gene chips will be the direction of } \\
\text { biotechnology development in China." }\end{array}$ & $\begin{array}{l}\text { "The technology I have mastered is cutting-edge, even in developed } \\
\text { countries. There are no more than two factories in the world that can } \\
\text { produce this chip. If I can bring this technology back and found a } \\
\text { firm, my company will be the third one in the world that can } \\
\text { industrialize the gene chip technology." }\end{array}$ \\
\hline B & $\begin{array}{l}\text { Bringing back } \\
\text { technology of } \\
\text { motor starting } \\
\text { system in a } \\
\text { new energy } \\
\text { automobile. }\end{array}$ & $\begin{array}{l}\text { "We see the great market potential and human resource } \\
\text { advantages in China. The large number of university-trained } \\
\text { engineering graduates as well as the trend of U.S. automobile } \\
\text { firms moving their outsourcing to China makes China an } \\
\text { attractive market." }\end{array}$ & $\begin{array}{l}\text { "I worked in a firm that specialized in manufacturing engines in the } \\
\text { U.S., where I led a team in developing the motor starting system of a } \\
\text { new energy automobile. Bringing the technology back to China } \\
\text { gives me a huge entrepreneurial opportunity." } \\
\text { "Chinese firms lack the ability to develop and manufacture core } \\
\text { components of the automobile, such as engine and transmission. We } \\
\text { can exploit our advantages in technology and have better } \\
\text { development." }\end{array}$ \\
\hline $\mathrm{C}$ & $\begin{array}{l}\text { Bringing back } \\
\text { technology of } \\
\text { industry } \\
\text { control system } \\
\text { that can } \\
\text { monitor the } \\
\text { Programmable } \\
\text { Logic } \\
\text { Controller } \\
\text { (PLC) system. }\end{array}$ & $\begin{array}{l}\text { "I had a lot of experience in this field and had researched in the } \\
\text { product, had contact with the Chinese market, and participated in } \\
\text { a Chinese project. I know that China's technological capability is } \\
\text { relatively weak in this field. I see a greater potential for the } \\
\text { application of the PLC control system in China. That's why I } \\
\text { considered starting a new company focusing on developing this } \\
\text { kind of product." }\end{array}$ & $\begin{array}{l}\text { "We have been working on developing prototype software in the } \\
\text { U.S. that can detect many errors in the PLC procedure. I think that } \\
\text { following this method will help improve control over the quality of } \\
\text { software, which is still a new and profitable area in China." }\end{array}$ \\
\hline $\mathrm{D}$ & $\begin{array}{l}\text { Bringing back } \\
\text { technology of } \\
\text { gear box } \\
\text { diagnosis and } \\
\text { maintenance } \\
\text { cost control }\end{array}$ & $\begin{array}{l}\text { "From my work experience and technology expertise, I know } \\
\text { exactly the needs and technology disadvantages of firms in the } \\
\text { equipment manufacturing industry (in China). In the U.S., the } \\
\text { coverage ratio of 'manufacturing condition monitoring' is about } \\
60 \text { percent. The percentage is much smaller in China. It means } \\
\text { that the U.S. finished this development } 10 \text { years ago, while China }\end{array}$ & $\begin{array}{l}\text { "I was working on this specific technology when I was in the U.S., } \\
\text { and there had been a theoretical breakthrough in the field. Therefore, } \\
\text { with the technology from the U.S. and the market size in China, the } \\
\text { entrepreneurial opportunity is large." } \\
\text { "China has very few firms working on this field because they } \\
\text { haven't completed the technological development in the core area. }\end{array}$ \\
\hline
\end{tabular}




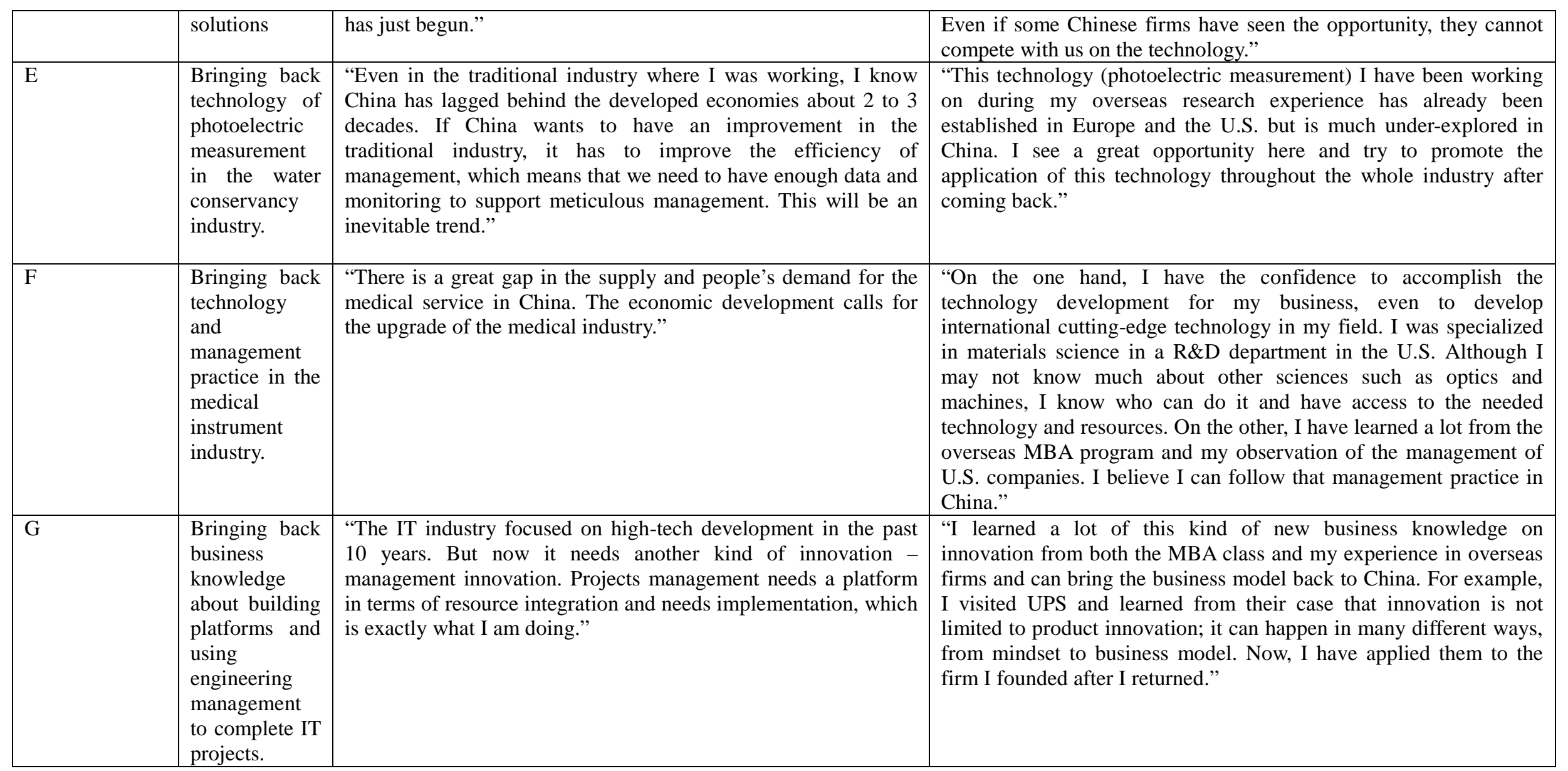




\section{Online Appendix}

\section{Appendix 1.}

Additional analysis 1: Do types of international knowledge transfer matter?

The following table and figures report the results of the first additional analysis, comparing the effects of transferring different types of knowledge on returnees' entrepreneurial decisions. We consider four scenarios: without international knowledge transfer, transferring only technological knowledge, transferring only business knowledge, and transferring both types of knowledge. We created three dummy variables, "Transferring only technological knowledge", "Transferring only business knowledge", and "Transferring both types of knowledge", to compare the last three scenarios to the baseline category: "without international knowledge transfer".

Table A1 Logistic regressions of transferring different types of knowledge on returnees' entrepreneurial decisions

\begin{tabular}{|c|c|c|c|c|c|}
\hline & Model 1 & Model 2 & Model 3 & Model 4 & Model 5 \\
\hline \multirow{2}{*}{ Gender } & -0.70 & $-1.26 *$ & $-1.44^{*}$ & -1.27 & $-1.63^{*}$ \\
\hline & $(0.55)$ & $(0.63)$ & $(0.68)$ & $(0.66)$ & $(0.73)$ \\
\hline \multirow[t]{2}{*}{ Age at return $(\log )$} & $3.20^{*}$ & 3.10 & 2.99 & $4.10^{*}$ & $4.05^{*}$ \\
\hline & $(1.47)$ & (1.59) & $(1.62)$ & (1.73) & (1.77) \\
\hline \multirow{2}{*}{ Overseas duration (log) } & -1.06 & -0.73 & -0.64 & -0.74 & -0.69 \\
\hline & $(0.62)$ & $(0.67)$ & $(0.70)$ & $(0.70)$ & $(0.75)$ \\
\hline \multirow[t]{2}{*}{ Number of host countries } & 0.04 & -0.04 & -0.05 & -0.04 & -0.05 \\
\hline & $(0.12)$ & $(0.12)$ & $(0.13)$ & $(0.13)$ & $(0.13)$ \\
\hline \multirow[t]{2}{*}{ Entrepreneurial attributes } & 0.92 & 0.45 & 0.45 & 0.71 & 0.84 \\
\hline & $(0.47)$ & $(0.53)$ & $(0.60)$ & $(0.57)$ & $(0.66)$ \\
\hline \multirow[t]{2}{*}{ Overseas doctoral degree } & 0.71 & 0.38 & 0.26 & 0.27 & 0.23 \\
\hline & $(0.51)$ & $(0.53)$ & $(0.56)$ & $(0.54)$ & $(0.58)$ \\
\hline \multirow[t]{2}{*}{ Overseas work experience (log) } & $1.12 *$ & 0.86 & 0.75 & 0.83 & 0.76 \\
\hline & $(0.56)$ & $(0.59)$ & $(0.60)$ & $(0.61)$ & $(0.63)$ \\
\hline \multirow[t]{2}{*}{ Overseas entrepreneurship experience } & $1.95 * *$ & $1.87^{* *}$ & $2.03^{* *}$ & $1.81^{* *}$ & $1.88^{* *}$ \\
\hline & $(0.59)$ & $(0.65)$ & $(0.68)$ & $(0.69)$ & $(0.71)$ \\
\hline \multirow[t]{2}{*}{ Major in sciences or engineering } & 0.06 & -0.03 & 0.12 & -0.04 & 0.18 \\
\hline & $(0.53)$ & $(0.59)$ & $(0.61)$ & $(0.61)$ & $(0.64)$ \\
\hline \multirow[t]{2}{*}{ Developed host country } & $1.09 *$ & $1.35^{* *}$ & $1.36^{*}$ & $1.17^{*}$ & $1.25^{*}$ \\
\hline & $(0.48)$ & $(0.52)$ & $(0.53)$ & $(0.54)$ & $(0.55)$ \\
\hline \multirow[t]{2}{*}{ Policy support for family } & 0.26 & 0.15 & 0.14 & 0.07 & 0.05 \\
\hline & $(0.20)$ & $(0.21)$ & $(0.22)$ & $(0.23)$ & $(0.25)$ \\
\hline \multirow[t]{2}{*}{ Strategic emerging industry } & $2.86^{* * *}$ & $2.76 * * *$ & $2.80^{* * *}$ & $2.99 * * *$ & $3.06^{* * *}$ \\
\hline & $(0.52)$ & $(0.56)$ & $(0.58)$ & $(0.60)$ & $(0.63)$ \\
\hline \multirow[t]{2}{*}{ Transferring only technological knowledge } & & $0.67 *$ & $0.72 *$ & $0.67 *$ & $0.75^{*}$ \\
\hline & & $(0.28)$ & $(0.30)$ & $(0.29)$ & $(0.31)$ \\
\hline \multirow[t]{2}{*}{ Transferring only business knowledge } & & 0.22 & 0.26 & 0.16 & 0.24 \\
\hline & & $(0.23)$ & $(0.24)$ & $(0.23)$ & $(0.25)$ \\
\hline \multirow[t]{2}{*}{ Transferring both types of knowledge } & & $1.23^{* * *}$ & $1.27^{* * *}$ & $1.20^{* * *}$ & $1.30 * * *$ \\
\hline & & $(0.33)$ & $(0.34)$ & $(0.35)$ & $(0.37)$ \\
\hline \multirow{2}{*}{ Perceived policy support for returnee entrepreneurship } & & & -0.02 & & -0.02 \\
\hline & & & $(0.27)$ & & $(0.27)$ \\
\hline \multirow{2}{*}{$\begin{array}{l}\text { Transferring only technological knowledge } \\
\text { x Perceived policy support for returnee entrepreneurship }\end{array}$} & & & 0.47 & & $0.61 *$ \\
\hline & & & $(0.27)$ & & $(0.30)$ \\
\hline \multirow{2}{*}{$\begin{array}{l}\text { Transferring only business knowledge } \\
\text { x Perceived policy support for returnee entrepreneurship }\end{array}$} & & & 0.12 & & 0.17 \\
\hline & & & $(0.28)$ & & $(0.28)$ \\
\hline \multirow{2}{*}{$\begin{array}{l}\text { Transferring both types of knowledge } \\
\text { x Perceived policy support for returnee entrepreneurship }\end{array}$} & & & 0.33 & & 0.49 \\
\hline & & & $(0.30)$ & & $(0.30)$ \\
\hline \multirow[t]{2}{*}{ Perceived readjustment difficulties of returnees } & & & & -0.56 & -0.48 \\
\hline & & & & $(0.32)$ & $(0.34)$ \\
\hline
\end{tabular}




\begin{tabular}{|c|c|c|c|c|c|}
\hline $\begin{array}{l}\text { Transferring only technological knowledge } \\
\text { x Perceived readjustment difficulties of returnees }\end{array}$ & & & & $\begin{array}{r}-\mathbf{0 . 3 9} \\
(0.27)\end{array}$ & $\begin{array}{r}-\mathbf{0 . 6 2} \\
(0.33)\end{array}$ \\
\hline \multirow[t]{2}{*}{$\begin{array}{l}\text { Transferring only business knowledge } \\
\text { x Perceived readjustment difficulties of returnees }\end{array}$} & & & & -0.19 & -0.34 \\
\hline & & & & $(0.23)$ & $(0.26)$ \\
\hline \multirow[t]{2}{*}{$\begin{array}{l}\text { Transferring both types of knowledge } \\
\text { x Perceived readjustment difficulties of returnees }\end{array}$} & & & & -0.69 & $-0.98 *$ \\
\hline & & & & $(0.38)$ & $(0.45)$ \\
\hline Home country location dummies & YES & YES & YES & YES & YES \\
\hline \multirow[t]{2}{*}{ Constant } & $-13.45^{* *}$ & $-12.50 *$ & $-12.06^{*}$ & $-15.77 * *$ & $-15.48 * *$ \\
\hline & (4.91) & $(5.32)$ & $(5.43)$ & (5.79) & (5.98) \\
\hline Chi2 & 120.59 & 136.99 & 140.74 & 143.47 & 149.13 \\
\hline Log likelihood & -85.42 & -77.22 & -75.34 & -73.98 & -71.15 \\
\hline $\mathrm{N}$ & 217 & 217 & 217 & 217 & 217 \\
\hline
\end{tabular}

Note:

- Comparing different types of knowledge to the baseline category-without international knowledge transfer-shows that transferring only technological knowledge and transferring both types of knowledge have significantly positive effects on returnees' entrepreneurial decisions ( $r=0.67, p=0.02$ and $r=1.23$, $\mathrm{p}=0.000$ in Model 2 of Table A1), while transferring only business knowledge does not have a significant relationship with returnees' entrepreneurial decisions $(\mathrm{p}=0.32)$.

- We compare the different effects on returnees' entrepreneurial decisions between transferring only technological knowledge and transferring only business knowledge. According to a one-degree-of-freedom test comparing the means, we find no significant difference between the effects of the two types of international knowledge transfer on returnees' entrepreneurial decisions $(p=0.29)$.

- We also test whether it makes a difference when transferring a combination of technological and business knowledge compared with transferring only technological knowledge and transferring only business knowledge. By performing the one-degree-of-freedom test comparing the means, we found that there is a slightly significant difference between transferring both types of knowledge and transferring only technological knowledge $(\mathrm{p}=0.08)$ and a very significant difference between transferring both types of knowledge and transferring only business knowledge $(\mathrm{p}=0.01)$ on returnees' entrepreneurial decisions.

- Because the coefficients of interactions in nonlinear models do not necessarily represent the sign, statistical significance and magnitude of conditional effects, we used the Marginsplot command introduced in STATA version 12 to generate graphical displays of the interaction effects (Figure A1-1 and Figure A1-2). 
Figure A1-1. Graphic presentations of different moderation effects for transferring only technological knowledge and transferring only business knowledge

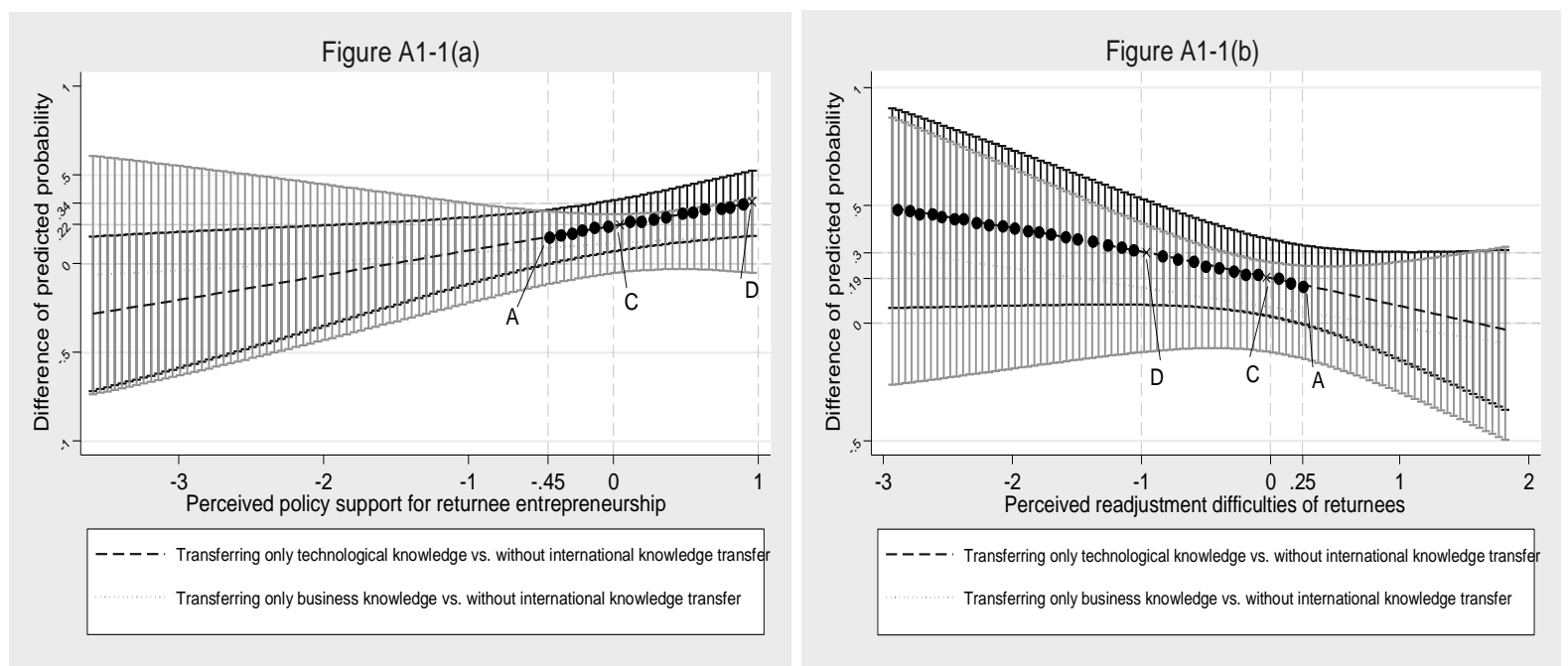

Notes:

- The y-axis in Figure A1-1(a) represents the difference in the predicted probabilities of entrepreneurial decisions for returnees who transfer only technological knowledge (dashed line) or returnees who transfer only business knowledge (dotted line) compared with returnees without international knowledge transfer against Perceived policy support for returnee entrepreneurship (x-axis). All other explanatory variables are held at the mean values in Model 3 of Table A1. The solid circles on the line indicate the range at which the difference is statistically significant at the 0.05 level. It shows that the contingent effects of perceived policy support for returnee entrepreneurship on transferring only technological knowledge is significant when the factor score of perceived policy support for returnee entrepreneurship is above -0.45 (to the right of Point A, 75\% of the observations), while the perceived policy support for returnee entrepreneurship has no significant moderating effects on the relationship between transferring only business knowledge and returnees' entrepreneurial decisions. The effect size of the moderation effect for the returnees who transfer only technological knowledge is $12 \%$ (from Point C to Point D)

- The y-axis in Figure A1-2 represents the difference in the predicted probabilities of entrepreneurial decisions for returnees who transfer only technological knowledge (dashed line) or returnees who transfer only business knowledge (dotted line) compared with returnees without international knowledge transfer against Perceived readjustment difficulties of returnees (x-axis). All other explanatory variables are held at the mean values in Model 4 of Table A1. The solid circles on the line indicate the range at which the difference is statistically significant at the 0.05 level. It shows that the contingent effects of perceived readjustment difficulties of returnees on transferring only technological knowledge is significant when the factor score of the perceived readjustment difficulties of returnees is below 0.25 (to the left of Point A, 61\% of the observations), while the perceived readjustment difficulties of returnees have no significant moderating effects on the relationship between transferring only business knowledge and returnees' entrepreneurial decisions. The effect size of the moderation effect for the returnees who transfer only technological knowledge is $11 \%$ (from Point C to Point D). 
Figure A1-2. Graphic presentations of different moderation effects for transferring both types of knowledge and transferring only one type of knowledge
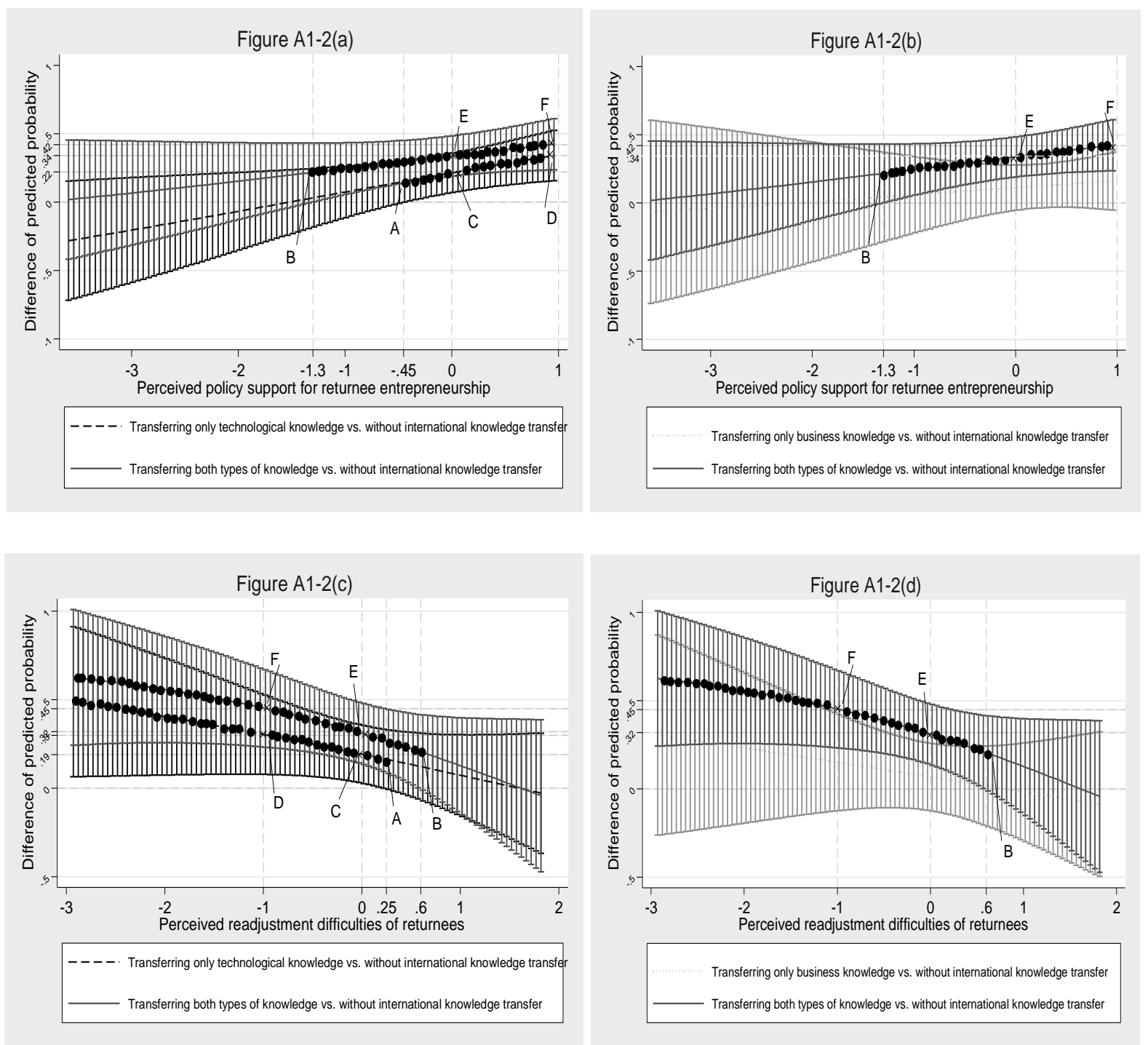

Notes:

- The y-axis in Figure A1-2 represents the difference in the predicted probabilities of entrepreneurial decisions for returnees who transfer only one type of knowledge (technological knowledge as a dashed line in Figure A1-2(a) and (c) or business knowledge as a dotted line in Figure A1-2(b) and (d)) and returnees who transfer both types of knowledge (solid line) compared with returnees without international knowledge transfer against Perceived policy support for returnee entrepreneurship (x-axis of Figure A1-2(a) and (b)) or Perceived readjustment difficulties of returnees (x-axis of Figure A1-2(c) and (d)). All other explanatory variables are held at the mean values in Model 4 of Table A1. The solid circles on each line indicate the range at which the difference is statistically significant at the 0.05 level.

- Figure A1-2(a) and A1-2(b) shows that the contingent effects of perceived policy support for returnee entrepreneurship on transferring only technological knowledge is significant when the factor score of perceived policy support for returnee entrepreneurship is above -0.45 (to the right of Point $\mathrm{A}, 75 \%$ of the observations) and that the contingent effects on transferring both types of knowledge is significant when the factor score of perceived policy support for returnee entrepreneurship is above -1.3 (to the right of Point B, $91 \%$ of the observations), while the perceived policy support for returnee entrepreneurship has no significant moderating effects on the relationship between transferring only business knowledge and returnees' entrepreneurial decisions. The effect size of the moderation effect for the returnees who transfer 
only technological knowledge is $12 \%$ (from Point C to Point D), and that for the returnees who transfer both types of knowledge is $8 \%$ (from Point $\mathrm{E}$ to Point F).

- Figure A1-2(c) and A1-2(d) shows that the contingent effects of perceived readjustment difficulties of returnees on transferring only technological knowledge is significant when the factor score of the perceived readjustment difficulties of returnees is below 0.25 (to the left of Point $\mathrm{A}, 61 \%$ of the observations) and that the contingent effects on transferring both types of knowledge is significant when the factor score of the perceived readjustment difficulties of returnees is below 0.6 (to the left of Point $\mathrm{B}, 72 \%$ of the observations), while the perceived readjustment difficulties of returnees have no significant moderating effects on the relationship between transferring only business knowledge and returnees' entrepreneurial decisions. The effect size of the moderation effect for the returnees who transfer only technological knowledge is $11 \%$ (from Point C to Point D), and that for the returnees who transfer both types of knowledge is $13 \%$ (from Point E to Point F). 


\section{Appendix 2.}

Additional analysis 2: Do advancement levels of international knowledge transfer matter?

The following table and figures report the results of our additional analysis comparing the effects of transferring knowledge new only to the home country and transferring cutting-edge knowledge on returnees' entrepreneurial decisions. The two dummy variables, "Transferring knowledge new only to the home country" and "Transferring cutting-edge knowledge", compare the two levels of international knowledge transfer to the baseline category: "without international knowledge transfer".

Table A2. Logistic regression of international knowledge transfer with different advancement levels on returnees' entrepreneurial decisions.

\begin{tabular}{|c|c|c|c|c|c|}
\hline & Model 1 & Model 2 & Model 3 & Model 4 & Model 5 \\
\hline \multirow[t]{2}{*}{ Gender } & -0.7 & -1.10 & -1.20 & -1.12 & $-1.35^{*}$ \\
\hline & $(0.55)$ & $(0.60)$ & $(0.63)$ & $(0.63)$ & $(0.69)$ \\
\hline \multirow[t]{2}{*}{ Age at return $(\log )$} & $3.20^{*}$ & 2.47 & 2.29 & $3.90 *$ & $3.66^{*}$ \\
\hline & $(1.47)$ & (1.53) & $(1.55)$ & $(1.70)$ & $(1.72)$ \\
\hline \multirow[t]{2}{*}{ Overseas duration (log) } & -1.06 & -0.77 & -0.78 & -0.76 & -0.83 \\
\hline & $(0.62)$ & $(0.66)$ & $(0.68)$ & $(0.70)$ & $(0.74)$ \\
\hline \multirow[t]{2}{*}{ Number of host countries } & 0.04 & -0.02 & 0 & -0.04 & -0.02 \\
\hline & $(0.12)$ & $(0.12)$ & $(0.13)$ & $(0.13)$ & $(0.13)$ \\
\hline \multirow[t]{2}{*}{ Entrepreneurial attributes } & 0.92 & 0.52 & 0.38 & 0.6 & 0.45 \\
\hline & $(0.47)$ & $(0.50)$ & $(0.59)$ & $(0.53)$ & $(0.61)$ \\
\hline \multirow[t]{2}{*}{ Overseas doctoral degree } & 0.71 & 0.42 & 0.39 & 0.43 & 0.44 \\
\hline & $(0.51)$ & $(0.53)$ & $(0.55)$ & $(0.55)$ & $(0.57)$ \\
\hline \multirow[t]{2}{*}{ Overseas work experience (log) } & $1.12 *$ & 1.03 & 0.97 & 0.95 & 0.95 \\
\hline & $(0.56)$ & $(0.57)$ & $(0.59)$ & $(0.60)$ & $(0.62)$ \\
\hline \multirow[t]{2}{*}{ Overseas entrepreneurship experience } & $1.95^{* *}$ & $1.79 * *$ & $1.98 * *$ & $1.87 * *$ & $2.02 * *$ \\
\hline & $(0.59)$ & $(0.61)$ & $(0.64)$ & $(0.64)$ & $(0.66)$ \\
\hline \multirow[t]{2}{*}{ Major in sciences or engineering } & 0.06 & 0.04 & 0.14 & 0.19 & 0.38 \\
\hline & $(0.53)$ & $(0.56)$ & $(0.58)$ & $(0.57)$ & $(0.60)$ \\
\hline \multirow[t]{2}{*}{ Developed host country } & $1.09 *$ & $1.25^{*}$ & $1.34 * *$ & $1.19 *$ & $1.33^{*}$ \\
\hline & $(0.48)$ & $(0.50)$ & $(0.52)$ & $(0.53)$ & $(0.55)$ \\
\hline \multirow[t]{2}{*}{ Policy support for returnee family } & 0.26 & 0.25 & 0.27 & 0.27 & 0.31 \\
\hline & $(0.20)$ & $(0.20)$ & $(0.21)$ & $(0.22)$ & $(0.24)$ \\
\hline \multirow[t]{2}{*}{ Strategic emerging industry } & $2.86^{* * *}$ & $2.74 * * *$ & $2.76^{* * *}$ & $2.86^{* * *}$ & $2.85^{* * *}$ \\
\hline & $(0.52)$ & $(0.54)$ & $(0.55)$ & $(0.58)$ & $(0.59)$ \\
\hline \multirow[t]{2}{*}{ Transferring knowledge new only to the home country } & & $0.55^{*}$ & $0.59 *$ & $0.55^{*}$ & $0.63 *$ \\
\hline & & $(0.24)$ & $(0.25)$ & $(0.25)$ & $(0.26)$ \\
\hline \multirow[t]{2}{*}{ Transferring cutting-edge knowledge } & & $0.81 * *$ & $0.86 * *$ & $0.81 * *$ & $0.90^{* *}$ \\
\hline & & $(0.29)$ & $(0.30)$ & $(0.29)$ & $(0.31)$ \\
\hline \multirow[t]{2}{*}{ Perceived policy support for returnee entrepreneurship } & & & 0.06 & & 0.02 \\
\hline & & & $(0.26)$ & & $(0.29)$ \\
\hline \multirow[t]{2}{*}{$\begin{array}{l}\text { Transferring knowledge only new to the home country } \\
\text { x Perceived policy support for returnee entrepreneurship }\end{array}$} & & & 0.1 & & 0.22 \\
\hline & & & $(0.25)$ & & $(0.29)$ \\
\hline \multirow[t]{2}{*}{$\begin{array}{l}\text { Transferring cutting-edge knowledge } \\
\text { x Perceived policy support for returnee entrepreneurship }\end{array}$} & & & 0.49 & & $0.68 *$ \\
\hline & & & $(0.27)$ & & $(0.32)$ \\
\hline \multirow[t]{2}{*}{ Perceived readjustment difficulties of returnees } & & & & -0.53 & -0.42 \\
\hline & & & & $(0.28)$ & $(0.30)$ \\
\hline \multirow[t]{2}{*}{$\begin{array}{l}\text { Transferring knowledge only new to the home country } \\
\text { x Perceived readjustment difficulties of returnees }\end{array}$} & & & & -0.23 & -0.42 \\
\hline & & & & $(0.24)$ & (0.29) \\
\hline
\end{tabular}




\begin{tabular}{rrrrr} 
& & & $\mathbf{- 0 . 7 3 *}$ & $\mathbf{- 0 . 9 9 * *}$ \\
& & & $(0.31)$ & $(0.38)$ \\
YES & YES & YES & YES & YES \\
$-13.45^{* *}$ & $-10.68^{*}$ & $-10.01+$ & $-15.72 * *$ & $-14.73 *$ \\
$(4.91)$ & $(5.12)$ & $(5.19)$ & $(5.74)$ & $(5.83)$ \\
120.59 & 129.61 & 133.78 & 138.12 & 144.08 \\
-85.41 & -80.91 & -78.82 & -76.65 & -73.67 \\
217 & 217 & 217 & 217 & 217 \\
\hline
\end{tabular}

Home country location dummies

Constant

$-13.45^{* *}$

$-10.68 *$

$-10.01+$

Chi2

Log likelihood

217

${ }^{*} \mathrm{p}<0.05, * * \mathrm{p}<0.01, * * * \mathrm{p}<0.001$

Note:

- Both levels of international knowledge transfer have significant positive effects on returnees' entrepreneurial decisions $(r=0.55, p=0.02$ and $r=0.81, p=0.004$ in Model 2 of Table A2). According to a one-degree-of-freedom test comparing the means, there is no significant difference between the effects of the two levels of knowledge transfer $(\mathrm{p}=0.59)$, indicating that neither transferring knowledge that is new only to the home country nor transferring cutting-edge knowledge influence returnees' entrepreneurial decisions.

- Because the coefficients of interactions in nonlinear models do not necessarily represent the sign, statistical significance and magnitude of conditional effects, we used the Marginsplot command introduced in STATA version 12 to generate graphical displays of the interaction effects (Figure A2-1 and Figure A2-2). 
Figure A2-1. Graphic presentations of the interaction between Transferring knowledge new only to the home country / Transferring cutting-edge knowledge and Perceived policy support for returnee entrepreneurship.

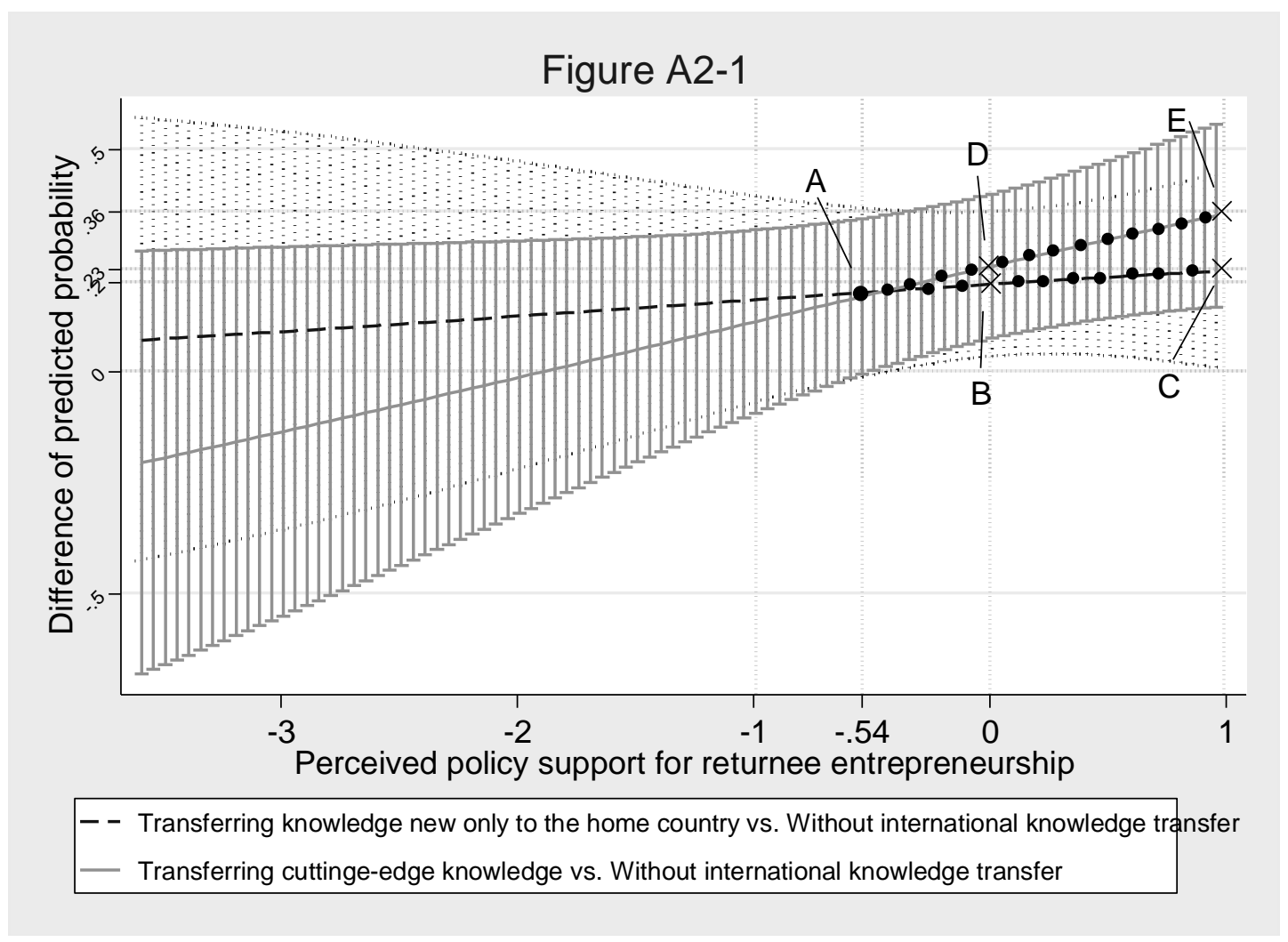

Notes:

- The y-axis in Figure A2-1 represents the difference in the predicted probabilities of entrepreneurial decisions for returnees who transfer cutting-edge knowledge (solid line) or returnees who transfer knowledge new only to the home country (dashed line) compared with returnees without international knowledge transfer against Perceived policy support for returnee entrepreneurship (x-axis). All other explanatory variables are held at the mean values in Model 3 of Table A2. The solid circles on each line indicate the range at which the difference is statistically significant at the 0.05 level.

- Figure A2-1 shows that the contingent effects of perceived policy support for returnee entrepreneurship on transferring cutting-edge knowledge and transferring knowledge that is new only to the home country are both statistically significant when the factor score of perceived policy support for returnee entrepreneurship is above -0.54 (to the right of Point A, 77\% of the observations). The effect size of the moderation effect for the returnees who transfer cutting-edge knowledge is $13 \%$ (from Point D to Point E), and that for the returnees who transfer knowledge that is new only to the home country is $3 \%$ (from Point B to Point C). 
Figure A2-2. Graphic presentations of the interaction between Transferring knowledge new only to the home country / Transferring cutting-edge knowledge and Perceived readjustment difficulties of returnees.

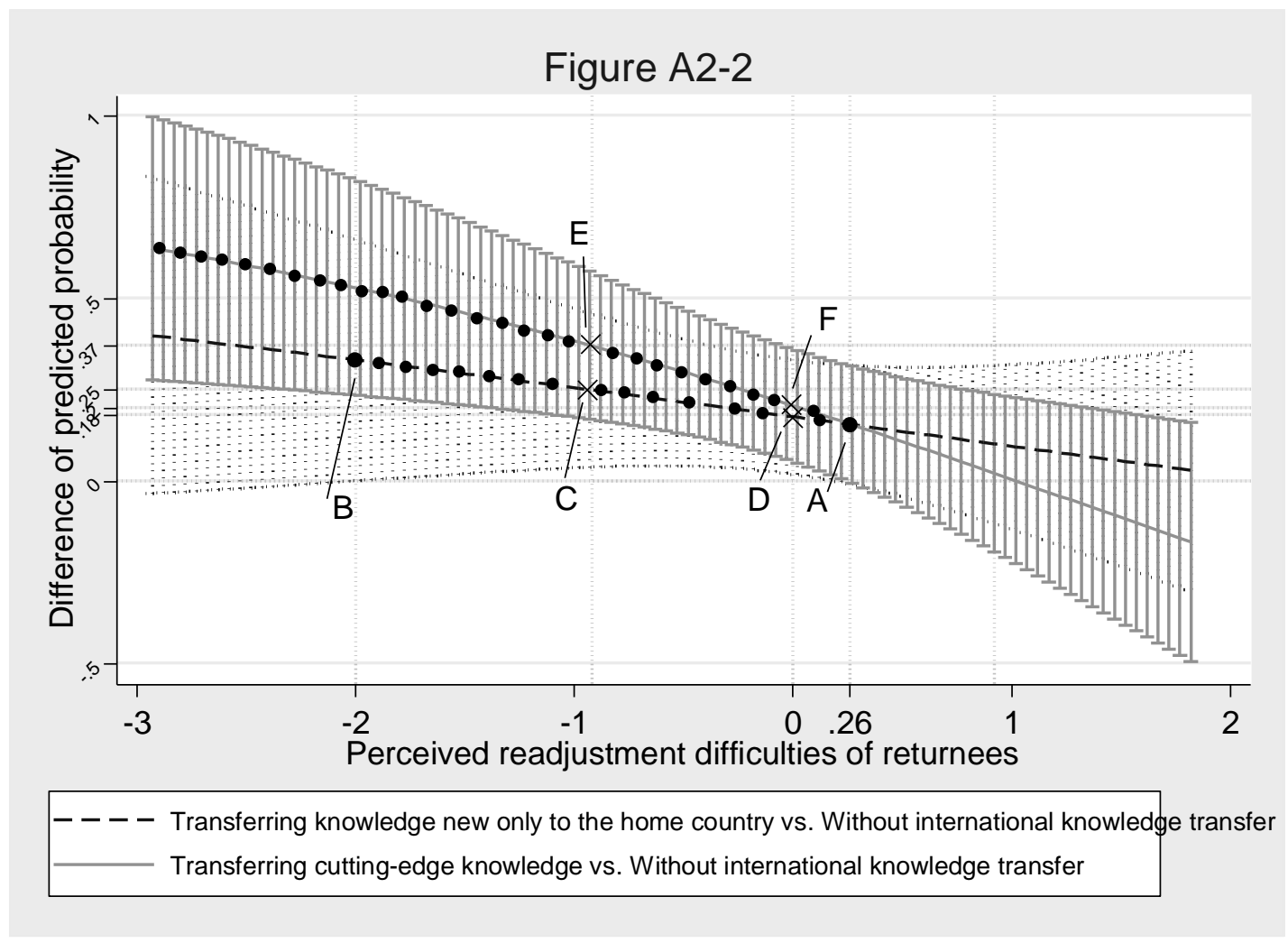

Notes:

- The y-axis in Figure A2-2 represents the difference in the predicted probabilities of entrepreneurial decisions for returnees who transfer cutting-edge knowledge (solid line) or returnees who transfer knowledge new only to the home country (dashed line) compared with returnees without international knowledge transfer against Perceived readjustment difficulties of returnees (x-axis). All other explanatory variables are held at the mean values in Model 4 of Table A2. The solid circles on each line indicate the range at which the difference is statistically significant at the 0.05 level.

- Figure A2-2 shows that the contingent effects of perceived readjustment difficulties of returnees in transferring cutting-edge knowledge is statistically significant when the factor score of perceived readjustment difficulties of returnees is below 0.26 (to the left of Point $A, 61 \%$ of the observations), and that in transferring knowledge that is new only to the home country is statistically significant when the factor score of perceived readjustment difficulties of returnees is between -2 and 0.26 (between Point $\mathrm{A}$ and Point B, 59\% of the observations). The effect size of the moderation effect for the returnees who transfer cutting-edge knowledge is 17\% (from Point $\mathrm{E}$ to Point $\mathrm{F}$ ), and that for the returnees who transfer knowledge that is new only to the home country is 7\% (from Point C to Point D). 